\title{
The cell-cell junctions of mammalian testes: I. The adhering junctions of the seminiferous epithelium represent special differentiation structures
}

\author{
Lisa M. Domke • Steffen Rickelt • Yvette Dörflinger • \\ Caecilia Kuhn • Stefanie Winter-Simanowski • Ralf Zimbelmann • \\ Rina Rosin-Arbesfeld • Hans Heid • Werner W. Franke
}

Received: 14 March 2014 / Accepted: 28 April 2014 / Published online: 8 June 2014

(C) The Author(s) 2014. This article is published with open access at Springerlink.com

\begin{abstract}
The seminiferous tubules and the excurrent ducts of the mammalian testis are physiologically separated from the mesenchymal tissues and the blood and lymph system by a special structural barrier to paracellular translocations of molecules and particles: the "blood-testis barrier", formed by junctions connecting Sertoli cells with each other and with spermatogonial cells. In combined biochemical as well as light and electron microscopical
\end{abstract}

Electronic supplementary material The online version of this article (doi:10.1007/s00441-014-1906-9) contains supplementary material, which is available to authorized users.

L. M. Domke · S. Rickelt • Y. Dörflinger · C. Kuhn ·

S. Winter-Simanowski $\cdot$ R. Zimbelmann $\cdot$ H. Heid $•$

W. W. Franke $(\bowtie)$

Helmholtz Group for Cell Biology, German Cancer Research Center (DKFZ), Im Neuenheimer Feld 280, 69120 Heidelberg, Germany

e-mail: w.franke@dkfz.de

L. M. Domke

Brandenburg University of Technology,

Senftenberg, Germany

C. Kuhn $\cdot$ W. W. Franke

Progen Biotechnik GmbH, Heidelberg, Germany

R. Rosin-Arbesfeld

Department of Anatomy, Sackler School of Medicine,

Tel-Aviv University, Tel-Aviv, Israel

Present Address:

L. M. Domke

Whitehead Institute for Biomedical Research, Massachusetts

Institute of Technology (MIT), Cambridge, MA, USA

Present Address:

S. Rickelt

David H. Koch Institute for Integrative Cancer Research,

Massachusetts Institute of Technology (MIT), Cambridge, MA, USA studies we systematically determine the molecules located in the adhering junctions of adult mammalian (human, bovine, porcine, murine, i.e., rat and mouse) testis. We show that the seminiferous epithelium does not contain desmosomes, or "desmosome-like" junctions, nor any of the desmosome-specific marker molecules and that the adhering junctions of tubules and ductules are fundamentally different. While the ductules contain classical epithelial cell layers with E-cadherin-based adherens junctions (AJs) and typical desmosomes, the Sertoli cells of the tubules lack desmosomes and "desmosome-like" junctions but are connected by morphologically different forms of AJs. These junctions are based on N-cadherin anchored in cytoplasmic plaques, which in some subforms appear thick and dense but in other subforms contain only scarce and loosely arranged plaque structures formed by $\alpha$ - and $\beta$ catenin, proteins p120, p0071 and plakoglobin, together with a member of the striatin family and also, in rodents, the proteins ZO-1 and myozap. These N-cadherin-based AJs also include two novel types of junctions: the "areae adhaerentes", i.e., variously-sized, often very large cell-cell contacts and small sieve-plate-like AJs perforated by cytoplasm-to-cytoplasm channels of 5-7 nm internal diameter ("cribelliform junctions"). We emphasize the unique character of this epithelium that totally lacks major epithelial marker molecules and structures such as keratin filaments and desmosomal elements as well as EpCAM- and PERP-containing junctions. We also discuss the nature, development and possible functions of these junctions.

Keywords Adherens junction · Desmosomes - Sertoli cells . Seminiferous tubules · Areae adhaerentes $\cdot$ Cribelliform junctions 


\section{Introduction}

A unique type of epithelium-like tissue element, in which somatic cell proliferation and differentiations occur side by side with meiotic divisions and male germ cell differentiation (spermatogenesis), is the tubulus seminiferus of the mammalian testis. Here, basal lamina-founded somatic cells, the "Sertoli cells", are laterally connected to each other and to spermatogenic cells with multiple cell-to-cell attachment structures (Dym and Fawcett 1970; Dym 1977; Russell and Peterson 1985; Pelletier 2001). Moreover, the Sertoli and the germ cells form an obviously tight-fitting barrier for paracellular translocations of molecules and particles, the tight junction-based blood-testis barrier (BTB) and support the development of the germ cells, at least up to the point of spermatid differentiation, in specific Sertoli cell indentations ("pockets") harboring the spermatid heads (e.g., Dym 1977; Vogl et al. 1991, 2008, 2013; Southwood and Gow 2001; Wong and Cheng 2005). Although prima facie the mature Sertoli cell layer looks like a typical epithelium, these cells are profoundly different from all other epithelial cells with respect to their biochemical and morphological components as well as their general architecture. This holds in particular for the absence of intermediate-sized filaments (IFs) of the keratin type, for the presence of vimentin IFs (Franke et al. 1979; see also Spruill et al. 1983; Paranko and Virtanen 1986; Franke et al. 1989; Stosiek et al. 1990; Steger and Wrobel 1994; Steger et al. 1994), for the additional occurrence of neurofilaments in human Sertoli cells (see, e.g., Davidoff et al. 1999) and for the presence of various types of specific adherens junctions (AJs) between the Sertoli cells (homotypic) and between Sertoli cells and spermatogonial cells in the basal part of the Sertoli cells (heterotypic-basolateral junctions) and between the adluminal pockets of the Sertoli cells and the spermatid heads (heterotypicapical junctions).

Originally, in the early years of transmission electron microscopy, certain AJs connecting Sertoli cells with each other or with spermatogonial cells had been seen as typical desmosomes or as desmosome-related and thus classified as "desmosomes", "rudimentary desmosomes", or "desmosomelike junctions" (e.g., Nicander 1967; Altorfer et al. 1974; Russell 1977a, b, c; Connell 1978; Nagano and Suzuki 1978; Osman 1978; Osman and Plöen 1978). Although our laboratory has repeatedly reported the total absence of both specific desmosomal structures and desmosomal marker molecules from Sertoli cells of the mature mammalian testis for more than three decades (e.g., Franke et al. 1979, 1981, 1982, 1983, 1986; 1989; Mueller and Franke 1983; Moll et al. 1986; Schmelz et al. 1986; Theis et al. 1993; see also Pelletier and Byers 1992; Schäfer et al. 1994; Nuber et al. 1995; Mertens et al. 1996), other authors have claimed, again and again, the occurrence of desmosomes or "desmosome-like" junctions in
Sertoli cells of mature mammals active in spermatogenesis (Vogl et al. 2008; Li et al. 2009; Lie et al. 2010, 2011; Cheng et al. 2011; Mruk and Cheng 2011; see Table 1 and Electronic Supplementary Material, Table S1). Because of this long and still ongoing controversy, the potential diagnostic value of molecular markers in histology and pathology and also in view of the worldwide interest in the development of male contraceptive agents based on the interference with cell-cell interactions in the testis (e.g., O'Donnell et al. 2000; Cheng and Mruk 2002, 2011, 2012; Lee and Cheng 2004; Mruk and Cheng 2004a, b; Wong et al. 2005; Xia et al. 2005; Lee et al. 2009; Mok et al. 2012, 2013a, b), we decided to study the cell biology of the tubuli seminiferi of diverse mammalian species. We were particularly interested in the connections and interactions of Sertoli cells with each other and with the spermatogonial cells. Therefore, we analyzed these interactions in ultrastructural and molecular biological detail using the

Table 1 Reports claiming that desmosomes or desmosome-like junctions or desmosome-specific molecules occur in the tubuli seminiferi of mammalian testes (only references since 1983 are considered here, as identifications using molecule-specific antibodies against desmosomal components have been generally available since that year); for complete references, see Electronic Supplementary Material, Table S1

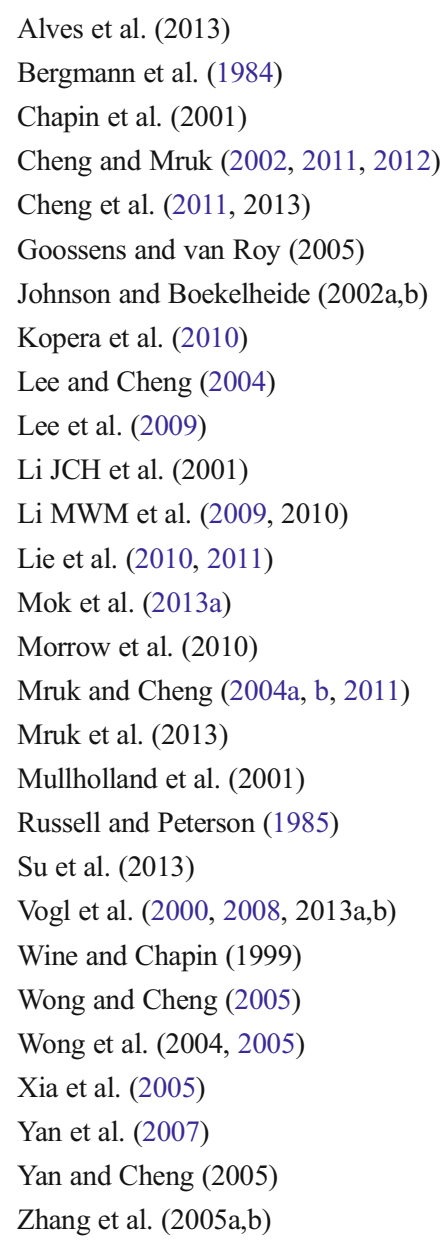


epithelium of the excurrent duct system as parallel controls. The results concerning the adhering junctions of the tubuli seminiferi are presented in this report. Results on gap and tight junctions, other cell-cell adhesion structures, the junctions in the peritubular and interstitial cells of the testis, junctional and cytoskeletal structures identified in early developmental stages, in aged and pathological forms, and in cultured Sertoli cells will be dealt with in further publications.

\section{Materials and methods}

Tissues and cells

Bovine testicular tissue samples were obtained in the regional slaughterhouse (Mannheim, Germany). Murine (rat and mouse) testes from sexually mature animals were obtained from the Central Animal Laboratory of the German Cancer Research Center (Heidelberg, Germany; for details, see Franke et al. 2006, 2013). In addition, testis tissue specimens from 3-year-old boars of German landrace pigs were provided by the Institute of Farm Animal Genetics (Friedrich-LoefflerInstitute, Mariensee, Germany; cf. Rickelt et al. 2011). Cryopreserved and aldehyde-fixed human testis samples were obtained from surgical material taken, examined for diagnostic pathology and processed in compliance with the regulations of the Ethics Committees of the Universities of Heidelberg and Marburg (Germany; see also Langbein et al. 2003).

In general, the tissue samples were fixed at ca. $4{ }^{\circ} \mathrm{C}$ or at room temperature in most cases with $4 \%$ formaldehyde, freshly prepared from paraformaldehyde, or in phosphatebuffered saline (PBS), with or without millimolar additions of divalent cations and embedded in paraffin. Alternatively, the tissues was snap-frozen in isopentane that had been precooled in liquid nitrogen and then stored at $-80{ }^{\circ} \mathrm{C}$ until use (see references cited above). Suitable frozen tissue samples were used for preparations of "semi-thin" cryostat sections (ca. 5-15 $\mu \mathrm{m}$ thick), or thin sections for immunofluorescence microscopy (see below) and analyses by SDSpolyacrylamide gel electrophoresis (SDS-PAGE) of polypeptides and immunoblotting (see below).

\section{Antibodies}

The antibodies (Abs) used in immunofluorescence and immunoelectron microscopy or in immunoblotting analyses of gel-electrophoretically-separated polypeptides are listed in Supplementary Table S2. Antigen-bound primary Abs were visualized with goat anti-rabbit, goat anti-guinea pig, or goat anti-mouse $\operatorname{IgG}(\mathrm{H}+\mathrm{L})$ secondary Abs coupled to Cy3 (Dianova, Hamburg, Germany) or Alexa 488 (MoBiTec, Göttingen,
Germany). For immunoblot analysis, horseradish-peroxidaseconjugated secondary Abs were used (Dianova).

Gel electrophoresis and immunoblotting

Proteins of tissue samples, including microdissected ones, were analyzed by SDS-PAGE, followed by immunoblotting, as previously described (Rickelt et al. 2010, 2011; Straub et al. 2011; Pieperhoff et al. 2012). Usually 100-200 cryostat sections of ca. $5-15 \mu \mathrm{m}$ thickness were collected and proteins of tissue lysates were solubilized in the same sample buffer (cf. Pieperhoff et al. 2012; Franke et al. 2013). After homogenization, the tissue lysates were heated toand kept at - ca. $95{ }^{\circ} \mathrm{C}$ for $4-5 \mathrm{~min}$, then centrifuged at $15,000 \mathrm{~g}$ for $10 \mathrm{~min}$. Both the supernatant and the pelleted proteins and glycoproteins were subjected to SDS-PAGE, followed by transfer to polyvinylidene difluoride membranes (ImmobilonP; Millipore, Bedford, MA, USA). For immunoblot analyses, horseradish-peroxidase-conjugated secondary Abs were applied in combination with an enhanced chemiluminescence system (ECL; Fisher Scientific, Schwerte, Germany).

\section{Immunofluorescence microscopy}

The methods used for immunofluorescence microscopy have been described (Langbein et al. 2003; Franke et al. 2006, 2013, 2014; Rickelt et al. 2008, 2011; Pieperhoff et al. 2012; Rickelt 2012). The frozen tissue sections were mounted on coverslips, air-dried and fixed for 5 or $10 \mathrm{~min}$ in $-20{ }^{\circ} \mathrm{C}$ acetone. The specimens were rehydrated in PBS and preincubated in PBS containing 0.2 or $0.3 \%$ Triton X-100 for $5 \mathrm{~min}$ before application of the primary Abs. In parallel, the tissue samples were fixed for 5-7 $\mathrm{min}$ in PBS (pH 7.4) containing $2 \%$ formaldehyde, freshly prepared from paraformaldehyde and the cells were permeabilized with PBS containing 0.1 or $0.2 \%$ saponin (same $\mathrm{pH}$ value; $5 \mathrm{~min}$ ), followed by exposure to the specific primary Abs in PBS for $1 \mathrm{~h}$. Following several washes in PBS for 5-10 min each, the samples were exposed to the specific secondary Abs for $30 \mathrm{~min}$. After two or three washes for 5-10 $\mathrm{min}$ in PBS, the cell preparations or cryosections were rinsed in distilled water, fixed for 1 or $5 \mathrm{~min}$ in ethanol and mounted in Fluoromount $\mathrm{G}$ (Southern Biotech; obtained through Biozol Diagnostica, Eching, Germany). Finally, immunofluorescence microscopic images were recorded with an Axiophot II photomicroscope (Carl Zeiss, Jena, Germany), equipped with an AxioCam HR (Carl Zeiss). For confocal laser scanning microscopy, a Zeiss LSM 510 Meta instrument was used.

Electron and immunoelectron microscopy

The electron and immunoelectron microscopy protocols were essentially as described (see Langbein et al. 2003; Franke et al. 
2006, 2013; Rickelt et al. 2008, 2011). For immunoelectron microscopy of cryostat sections, the tissue samples were fixed in PBS containing 2 or $3 \%$ formaldehyde for 5-7 min and permeabilized with PBS containing $0.1 \%$ saponin (3-5 min), followed by incubation with primary Abs for at least $2 \mathrm{~h}$. After three washing steps, the samples were incubated with secondary Abs conjugated with 1.4-nm gold particles (Nanogold; Biotrend, Cologne, Germany) for $4 \mathrm{~h}$, followed by silver enhancement for various periods of time $(5,7$, or $9 \mathrm{~min})$. Electron micrographs were taken at $80 \mathrm{kV}$ in an EM 900 or EM 10 (Carl Zeiss) instrument.

\section{Results}

For comparison and control: the epithelia of the excurrent ducts

In all species examined, we used tissue samples from various portions of the excurrent ducts, which are known to contain typical simple or columnar epithelia, as controls of the methods applied and to determine the specificity of the antibodies used in immunocytochemistry of the seminiferous tubules (for references, see, e.g., Dym 1974, 1976, 1977; Kasper and Stosiek 1989; Cyr et al. 1995, 2007; Piomboni 1997; Pelletier 2001; DeBellefeuille et al. 2003). Frequently, it was possible for us to study testicular tissue containing seminiferous tubules in parallel with preparations of excurrent duct tissues, including the epididymis, from the same animal.

\section{Biochemical results}

When we compared the adhering junction proteins of specific intercepts or portions of the excurrent system with those of the seminiferous tubule system by gel electrophoresis and immunoblot identification, we observed striking differences (Fig. 1). Certain cytoskeletal control proteins such as actin and vimentin (Fig. 1a, j), as well as constituents known to occur in all kinds of AJs such as the armadillo-type plaque proteins $\beta$-catenin, protein $\mathrm{p} 120$ and plakoglobin, which is known also to occur in desmosomes (Cowin et al. 1986), were detected in all samples (e.g., Fig. 1f, g). Other molecules showed marked differences between the AJs of the excurrent duct and the seminiferous tubule epithelia. In all species examined, E-cadherin was found as a major component in all excurrent duct regions but was not detected in the semini[-]ferousrous epithelium (e.g., Fig. 1d, e; for a special minor non-epithelial cell type, see below). Vice versa, Ncadherin was present as a major component in the seminiferous tubule epithelia but was absent in the excurrent duct epithelia (e.g., Fig. 1b, c). No other AJ cadherins examined were found in either kind of epithelia, while the AJ plaque proteins, $\alpha$ - and $\beta$-catenin, p120, p0071, myozap and a member of the striatin family, were abundantly present in both excurrent duct and seminiferous tubule epithelia (see Table 2 for specific comments).

The results for desmosomal proteins of both kinds were very impressive and clear: As a representative example of the desmosomal cadherins, the absence of desmoglein Dsg-2 in the seminiferous tubules is shown in Fig. 1i and the absence of the plaque protein desmoplakin in Fig. 1h. Negative results in the seminiferous tubules were also obtained for desmocollin Dsc-2 and plakophilin Pkp-2 as well as molecules Dsg-1 and Dsg-3, Dsc-1 and Dsc-3 and Pkp-1 and Pkp-3 (not shown). In contrast, certain desmosomal molecules (Dsc-2, Dsg-2, Pkp-2 and desmoplakin) were abundantly present in all the epithelia of the excurrent duct system (Table 2).

The transmembrane proteins EpCAM and PERP, which were not detected in the seminiferous epithelia, were regular constituents of the subapical region close to the zonula adhaerens AJs of the excurrent ducts (these molecules will be specifically dealt with in one of the next publications in this series).

Immunofluorescence microscopy results

\section{Excurrent duct epithelia}

The results revealed in all the epithelia of the excurrent duct system a keratin IF cytoskeleton and an abundance of desmosomes that could generally be demonstrated by coimmunolocalization of the corresponding transmembrane and the cytoplasmic plaque molecules (Table 2; an example for desmoglein Dsg-2 and desmoplakin is shown in Electronic Supplementary Material, Fig. S1). By contrast, differential localization of E-cadherin and N-cadherin is seen in the tissues in which N-cadherin was selectively absent in the epithelia and only seen as a very minor element in some of the interstitial cells (Fig. 2). As to the cytoplasmic plaque proteins of the epithelial AJs, we noted that some occurred in all junction structures, i.e., zonula adhaerens plus fasciae adhaerentes and puncta adhaerentia, such as the catenins and protein p120 (Fig. 3a-a"), whereas others such as proteins myozap, p0071 and a member of the striatin family appeared to be largely restricted to the subapical zonula adhaerens (see, e.g., Fig. 3b). Protein PERP was a particularly prominent component associated with the zonula adhaerens structure (not shown; for comparison with other epithelia, see Franke et al. 2013) and specific zonula immunolocalizations were also noted with some of the antibodies directed against protein LUMA (cf. Franke et al. 2014). The massive aggregates of spermatozoa frequently seen in the lumina of these ductules were totally negative for the various junctional proteins examined (e.g., Figs. 2, 3). 


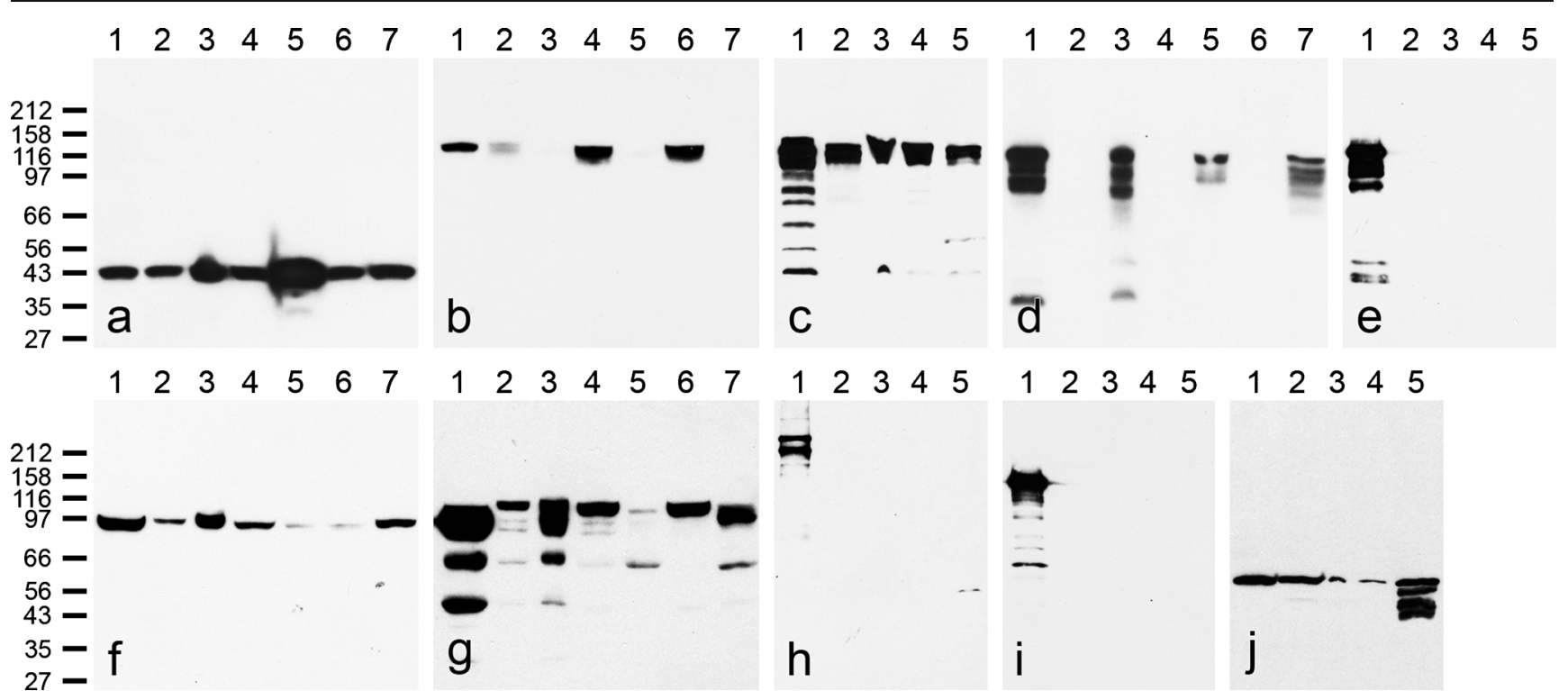

Fig. 1 Identification of proteins and glycoproteins of cell-cell adhering junctions in dissected tissue parts of mammalian testis, enriched in seminiferous tubules, or excurrent duct tissues, demonstrated after SDSPAGE of total protein lysates by immunoblotting with specific antibodies a Antibodies against $\beta$-actin identify a single polypeptide band at $43 \mathrm{kDa}$ in cultured human $\mathrm{HaCaT}$ keratinocytes (lane 1 in all blots shown, i.e. aj), bovine testis (lane 2) and epididymis (lane 3), boar testis (lane 4) and boar excurrent duct-containing tissue (lane 5), rat testis (lane 6) and rat excurrent duct tissue (lane 7). b Antibodies against N-cadherin recognize this glycoprotein in testicular tissue of bull (lane 2), boar (lane 4) and rat (lane 6) but not to a significant extent in excurrent duct tissues of bovine (lane 3), porcine (lane 5) and murine (rat, lane 7) origin. $\mathbf{c}$ As in (b), Ncadherin is detected to comparable intensities in near-equal amounts of testicular tissue of bovine (lane 2), rat (lane 3), mouse (lane 4) and human (lane 5) origin. $\mathbf{d}$ In a mutually exclusive way, E-cadherin is recognized in the excurrent duct tissues of bovine (lane 3), porcine (lane 5) and murine (rat, lane 7) origin but not in the corresponding testicular tissues enriched

\section{Seminiferous tubule epithelium}

In correspondence with the biochemical results (Fig. 1), the tubule cells of the layer lining the adluminal side of the basal lamina were positive for both vimentin IFs and N-cadherin AJs (Electronic Supplementary Material, Figs. S2, S3), the latter in confirmation of Cyr et al. (1992, 1993), Newton et al. (1993) and Byers et al. (1994) but negative for keratins (for references see "Introduction"), E-cadherin and all the other cadherins examined (Figs. 4, 5, 6, and 7), including P-cadherin, VE-cadherin and cadherin-11 (Table 2; see also Cyr et al. 1992). In addition, a surprising positive E-cadherin reaction was detected in a thin non-epithelial cell layer of the interstitium of the bovine testis, a so-called "myoid" cell layer surrounding the tubules (red-stained cell-cell junctions in Fig. 4a-a"'), a layer also positive for keratins 8 and 18 (cf. Electronic Supplementary Material, Fig. S2).

A very clear result of these immunolocalization experiments was that no significant reactions were seen for any of the cadherin family glycoproteins of either the desmoglein and

in seminiferous tubules (material in lanes 2, 4 and 6 of bovine, porcine, and murine origin). e E-cadherin is not detected in tissue material from microdissected testicular tissues enriched in seminiferous tubules of bovine (lane 2), rat (lane 3), mouse (lane 4) and human (lane 5) origin. $\mathbf{f}$ The major plaque protein of $\mathrm{AJ} s, \beta$-catenin, is detected in all these tissues (lanes $2-7$ as in a, b and $\mathbf{d}$ ), although in different intensities (note the weak reaction in lanes 5 and 6 ). g Similarly, the AJ plaque protein p120 is found in all samples, although at a rather low intensity in boar excurrent duct tissues (lane 5; note, however, a major proteolytic degradation product of about $62 \mathrm{kDa}$ in lanes 3, 5 and 7). h In comparison with human HaCaT keratinocytes (lane 1), desmoplakin is not recognized in bovine (lane 2), rat (lane 3), mouse (lane 4,) and human (lane 5) seminiferous tubules of testis. i Correspondingly, desmoglein Dsg-2 (HaCaT cells, lane 1) is not detected in bovine (lane 2), rat (lane 3), mouse (lane 4) and human (lane 5) testicular tissue containing seminiferous tubules. $\mathbf{j}$ Control showing the presence of vimentin in all tissues shown in $(\mathbf{h}-\mathbf{j})$

the desmocollin group, in particular not for Dsg-2 and Dsc-2 (see, e.g., Electronic Supplementary Material, Fig. S4a). Also negative were the reactions for the desmosomal plaque proteins desmoplakin (Fig. 5) and plakophilin Pkp-2 (e.g., Electronic Supplementary Material, Fig. S4b), or any other member of the plakophilin group (Table 2). These negative results were obtained for all desmosomal marker molecules using antibodies that abundantly demonstrated positivity in all the species studied.

The N-cadherin-positive, punctate or elongated junction structures were positive for several of the cytoplasmic plaque proteins of the armadillo family such as $\beta$-catenin (Fig. 5), plakoglobin (not shown; see Table 2 and Byers et al. 1994), proteins p0071 (Figs. 6 and 7) and p120. They were also immunostained with antibodies to the actin-interacting protein $\alpha$-catenin (for co-localization with $\beta$-catenin see Electronic Supplementary Material, Fig. S5; see also Table 2) as well as for the proteins myozap and striatin (Figs. 7 and 8; Table 2). On the other hand, the Sertoli cell membranes were totally negative for the transmembrane, junction-associated proteins 
Table 2 Homotypic adhering junctions: results of immunolocalization experiments (summary for all species examined)

\begin{tabular}{|c|c|c|}
\hline Molecule & $\begin{array}{l}\text { Sertoli-Sertoli and Sertoli- } \\
\text { Spermatogonia cell junctions }\end{array}$ & $\begin{array}{l}\text { Excurrent duct } \\
\text { epithelia }\end{array}$ \\
\hline \multicolumn{3}{|c|}{ Transmembrane glycoproteins (Cadherins) } \\
\hline E-cadherin & - & + \\
\hline VE-cadherin & - & - \\
\hline $\mathrm{N}$-cadherin & + & - \\
\hline P-cadherin & - & - \\
\hline Cadherin-11 & - & - \\
\hline Desmoglein 1 (Dsg-1) & - & - \\
\hline Desmoglein 2 (Dsg-2) & - & + \\
\hline Desmoglein 3 (Dsg-3) & - & - \\
\hline Desmocollin 1 (Dsc-1) & - & - \\
\hline Desmocollin 2 (Dsc-2) & - & + \\
\hline Desmocollin 3 (Dsc-3) & - & - \\
\hline \multicolumn{3}{|c|}{ Other transmembrane molecules } \\
\hline EpCAM & - & + \\
\hline Protein PERP & - & + \\
\hline \multicolumn{3}{|l|}{ Cytoplasmic plaque proteins } \\
\hline Desmoplakin I+II & - & + \\
\hline Plakophilin 1 & - & - \\
\hline Plakophilin 2 & - & + \\
\hline Plakophilin 3 & - & + \\
\hline$\beta$-Catenin & + & + \\
\hline Protein p120 & + & + \\
\hline Protein p0071 & + & + \\
\hline Plakoglobin & + & + \\
\hline Neurojungin & - & - \\
\hline$\alpha$-Catenin & + & + \\
\hline Protein ZO-1 & $(+/-)^{\mathrm{a}}$ & + \\
\hline Myozap & $(+/-)^{\mathrm{a}}$ & + \\
\hline Striatin $^{\mathrm{b}}$ & + & + \\
\hline Protein LUMA & - & + \\
\hline
\end{tabular}

${ }^{a}$ For unexplained reasons, we have consistently found reactions of the plaque proteins myozap and ZO-1 in adherens junctions of Sertoli cells in the rodent testes but not in the other species examined in which only the adherens junctions of the endothelial and some interstitial mesenchymal cells showed myozap- and/or ZO-1-positive junctions

${ }^{b}$ Whether it is striatin or a closely related member of the striatin family of proteins is not yet clear

PERP and EpCAM (Table 2; for comparison with positively stained cells, see, e.g., Rickelt et al. 2011; Pieperhoff et al. 2012; Franke et al. 2013).

\section{Electron microscopy}

As some of the AJ-related structures in the seminiferous tubules are rather small, others very complex or extremely large and some of them also appear to be organized in cell- type-specific ways, they were examined in detail by transmission electron microscopy and immunoelectron microscopy. Only the AJ-type structures connecting Sertoli cells with each other or with spermatogenic cells will be dealt with in the present report.

It is a striking observation that in well-fixed, optimally preserved tubuli seminiferi, the cells are intimately associated with each other by junction-like plasma membrane structures for very large proportions of the cell surface, often exceeding $50 \%$ (e.g., Fig. 9a-a'", b). This rather consistently close and parallel contact with a membrane-to-membrane distance of 8 $20 \mathrm{~nm}$ often appears to be accompanied by small and sparse submembranous densities, which are only loosely associated with the specific membrane regions (see, e.g., Fig. 9b-d). Such extended, close and parallel junctions are seen in both homotypic Sertoli cell associations as well as in Sertoli cell associations with spermatogenic cells.

In some regions of such plaque-based cell-cell associations, local differences of the intermembranous space are notable (Figs. 9d, 10a-c) and, in some of these junction-like structures, a linear punctate midline array of granular-looking "dots" 2 $5 \mathrm{~nm}$ in diameter is resolved (e.g., Fig. 10b, b', c; see also the junction denoted by an arrowhead in Fig. 10d"'). Closely spaced, small (diameters up to $500 \mathrm{~nm}$ ) AJ-like structures with rather irregularly contoured, electron-dense plaques appear as almost regular arrays, interrupted only by some direct membrane-membrane "touch sites" of an as yet unidentified molecular nature (Fig. 10d, bottom: the series of AJ contacts between cell 1 and cell 2; for details, see also Fig. 10d", d"'). Immunolocalization electron microscopy experiments published by Byers et al. (1991) and Pelletier and Byers (1992) have indicated the presence of protein ZO-1 at these sites that we can confirm. On the other hand, ZO-1-3 proteins cannot be considered unequivocal markers of tight junctions (TJs) as they have been identified in both $\mathrm{TJ}$ and AJ structures (for references. see, e.g., Franke 2010).

Some of these close membrane-to-membrane associations (Fig. 10a-d show many such cell-cell contact regions between several Sertoli cell processes, numbered 1-5) are accompanied in a conspicuous way by so-called "ectoplasmic specializations" (ES; for morphological and immunocytochemical references, see, e.g., Dym and Fawcett 1970; Russell 1977c; Franke et al. 1978; Russell and Peterson 1985; Vogl 1989; Vogl et al. 1991, 2000, 2008; Mruk and Cheng 2004a; Wong et al. 2005; Yan et al. 2007; Kopera et al. 2010; Cheng and Mruk 2012; Qian et al. 2013). These are paracrystalline actin microfilament bundles that, in some regions, are directly connected to the inner side of the plasma membrane by lateral, rather closely spaced, up to 4-nm-thick cross-bridge structures (see, e.g., the inset in Fig. 10d'), whereas other portions of such bundles may protrude into the cytoplasm (see, e.g., the cells labelled nos. 3 and 4 in Fig. 10d). Microfilament bundles of such ES structures, 

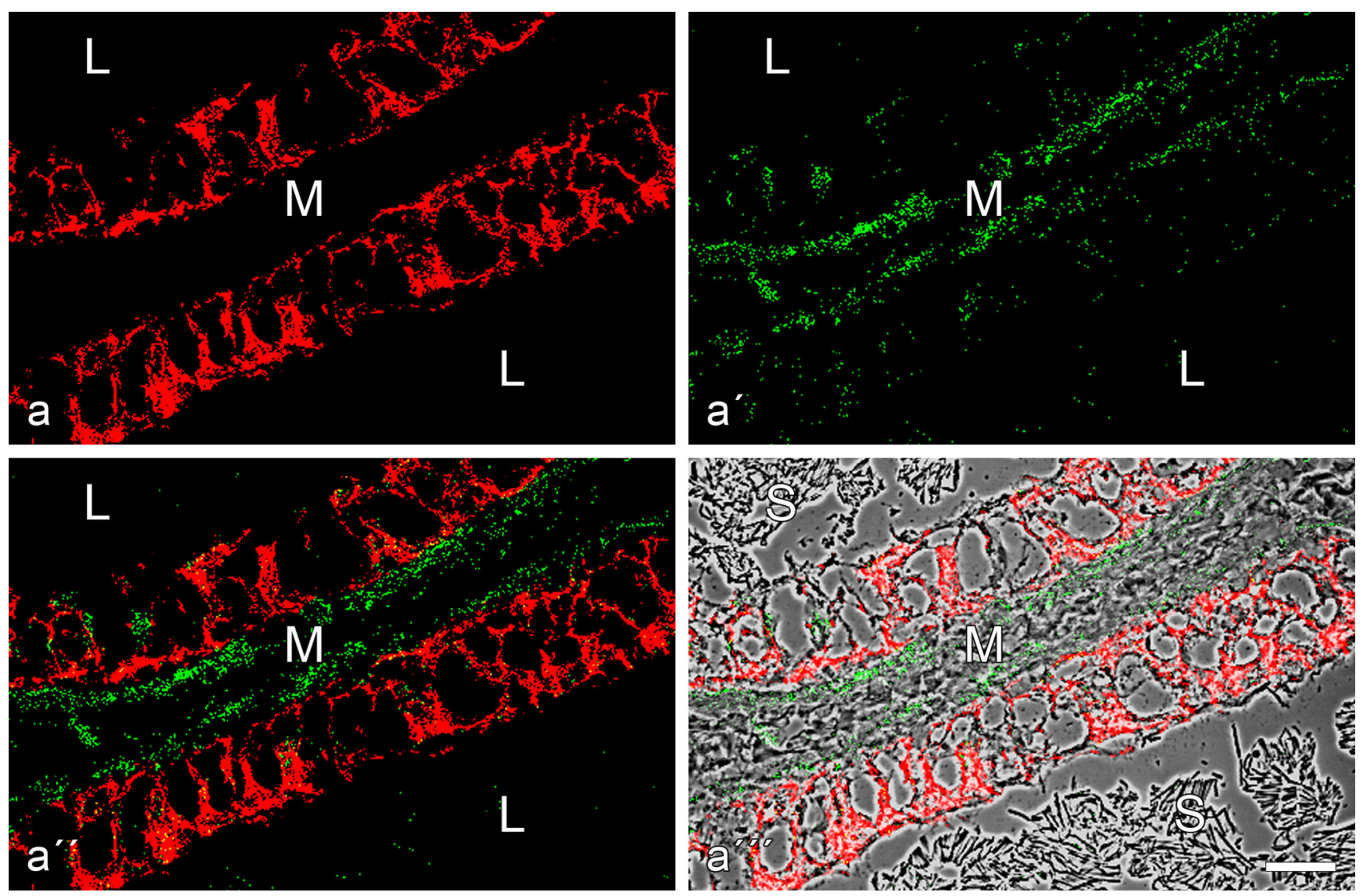

Fig. 2 Double-label immunofluorescence microscopy of a near-longitudinal cryostat section through frozen rat testis tissue containing excurrent ducts ( $L$ lumen; $M$ mesenchymal space with interstitial cells) after reactions with antibodies to E-cadherin (a, red) or N-cadherin ( $\mathbf{a}^{\prime}$, green), demonstrating the mutually exclusive localization of both cadherins (a"; $\mathbf{a}^{\text {"' }}$ with

associated with three or even more cells, were also repeatedly noted (e.g., Fig. 11d). Careful studies of the distributions of such ES structures have not allowed the identification of terminal associations ("anchorages") at AJ plaque structures.

While we have not yet been able to elucidate the molecular composition of the "close contact" intercepts between the plaque-bearing, ES-associated AJ structures (cf., e.g., arrows and arrowheads in Figs. 10d", d"', 11a), we often noted a fuzzy coating of electron-densely stained material at these structures (Figs. 10d, d", d"', 11h-j). Obviously, these rather loose but regular associations with the "close" junctions have also impressed some previous authors who have even included them in model drawings of such structures (see, e.g., Pelletier and Byers 1992). A most surprising substructure in these cell-cell contact regions were the relatively small, sieve-plate-like cribelliform junctions (areae cribelliformes) characterized by regularly sized, membranebounded cell-cell "channels" or "pores", often associated with short filamentous bundles (Fig. 11d-f; for similar short "bushes" of filaments, see also Fig. 3 of Connell 1978). phase contrast background). Note the extensive and intensive E-cadherin reaction along the plasma membranes of the ductal epithelium $\left(\mathbf{a}, \mathbf{a}^{\prime \prime}\right)$ as well as the weak reaction of N-cadherin in some of the interstitial cells of the mesenchyme (green in $\mathbf{a}^{\prime}$ ). Note that the ductal lumen is filled with masses of aggregated spermatozoa ( $S$ in $\mathbf{a}^{\prime \prime \prime)}$. Bar $20 \mu \mathrm{m}$

What was also conspicuous in these Sertoli cells was the abundance of bundles of vimentin IFs that did not insert at the AJs but were more or less parallel with respect to the plasma membrane as well as with the nuclear envelope (a typical overview is presented in Electronic Supplementary Material, Fig. S6; see also fig. 1 of Franke et al. 1979). Not infrequently, such vimentin IF bundles assumed almost paracrystalline order in which the IFs were separated by mean center-to-center distances of 10-25 nm (see, e.g., Electronic Supplementary Material, the bottom part of Fig. S6).

Immunoelectron microscopy

Our immunoelectron microscopic results confirmed the negative immunofluorescence reactions of all desmosome-specific proteins and glycoproteins (desmoplakin, plakophilins, desmogleins, and desmocollins) in the adult tubuli seminiferi of all the species examined (not shown). By contrast, we saw more or less continuous immunogold labeling along the Sertoli cell associations with other Sertoli cells or with spermatogonial 

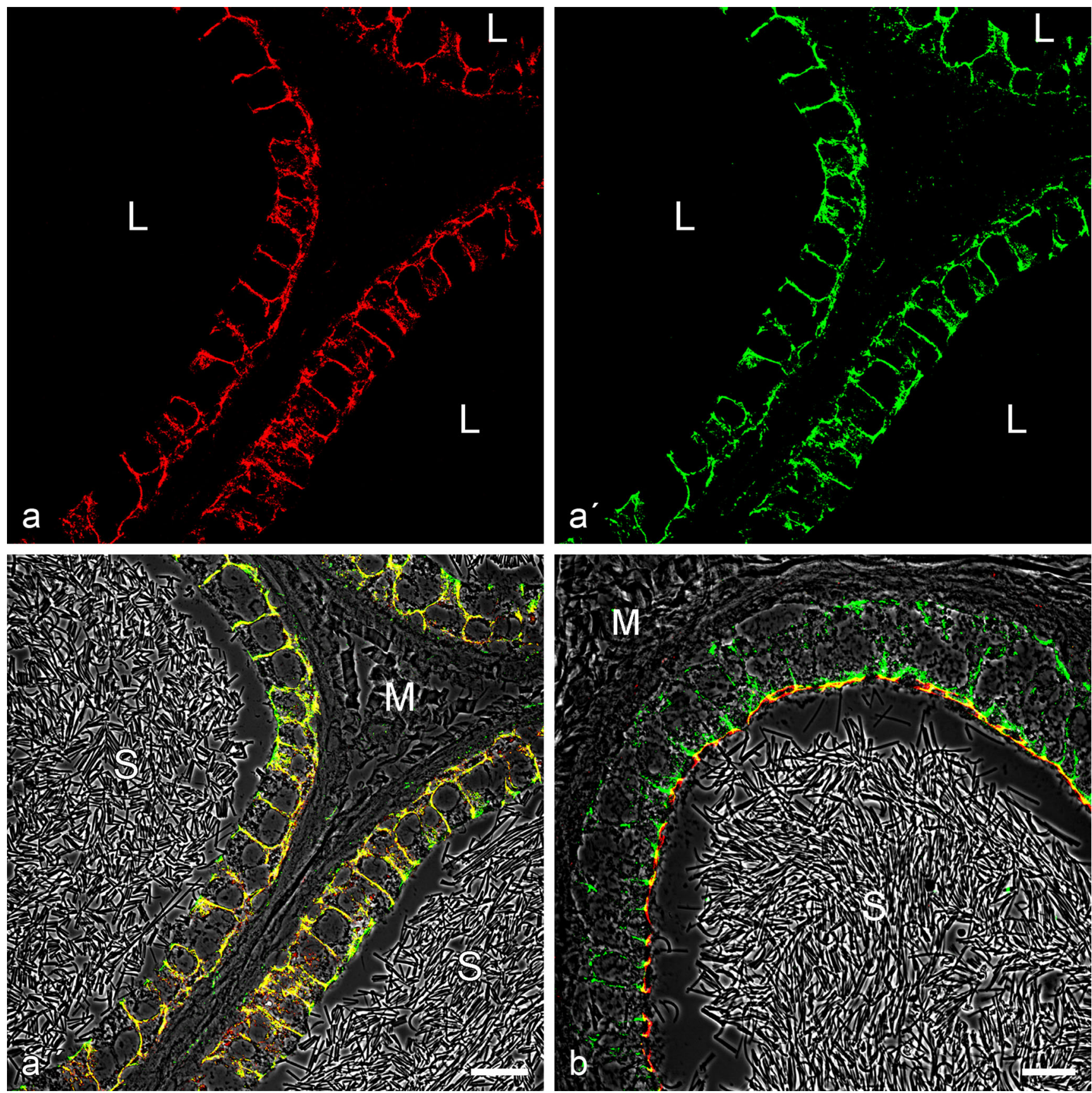

Fig. 3 This double-label immunofluorescence microscopy shows the specific immunostaining of the AJs connecting excurrent duct epithelial cells of rat testis after reactions with the armadillo plaque proteins p120 (a, red, mouse $\mathrm{mAb}$ ) and $\beta$-catenin ( $\mathbf{a}^{\prime}$, green, rabbit antibodies), resulting in colocalization indicated by the yellow merger staining (a", on a phase contrast background) in the subapical zonula adhaerens as well as in the numerous AJs along the lateral

cells. Examples for the armadillo plaque protein $\beta$-catenin are shown in Fig. 12a-d (the continuous-appearing labeled region in Fig. 12a, for example, is more than $6 \mu \mathrm{m}$ long; the regions shown in Fig. 12b-d are also very long). Similar results were obtained for N-cadherin (Fig. 12e) and the member of the striatin family present in the testis (Fig. 12f). membrane-membrane contacts. By contrast in (b), colocalization of $\beta$-catenin with the non-armadillo plaque protein, myozap (red, mouse $\mathrm{mAb}$ ), indicates that in this case protein myozap also occurs in the subapical zonula but is not detectable in significant amounts in most of the lateral membrane junctions. $L$ lumen; $M$ mesenchymal region; $S$ aggregates of spermatozoa. Bar $20 \mu \mathrm{m}$

\section{Discussion}

The Sertoli cells of the mature mammalian testis have to be classified as "epithelial" cells as they are based on a remarkably thick basal lamina, show a polar-basolateral-apicalarchitecture with lateral cell-cell junctions and border on a 

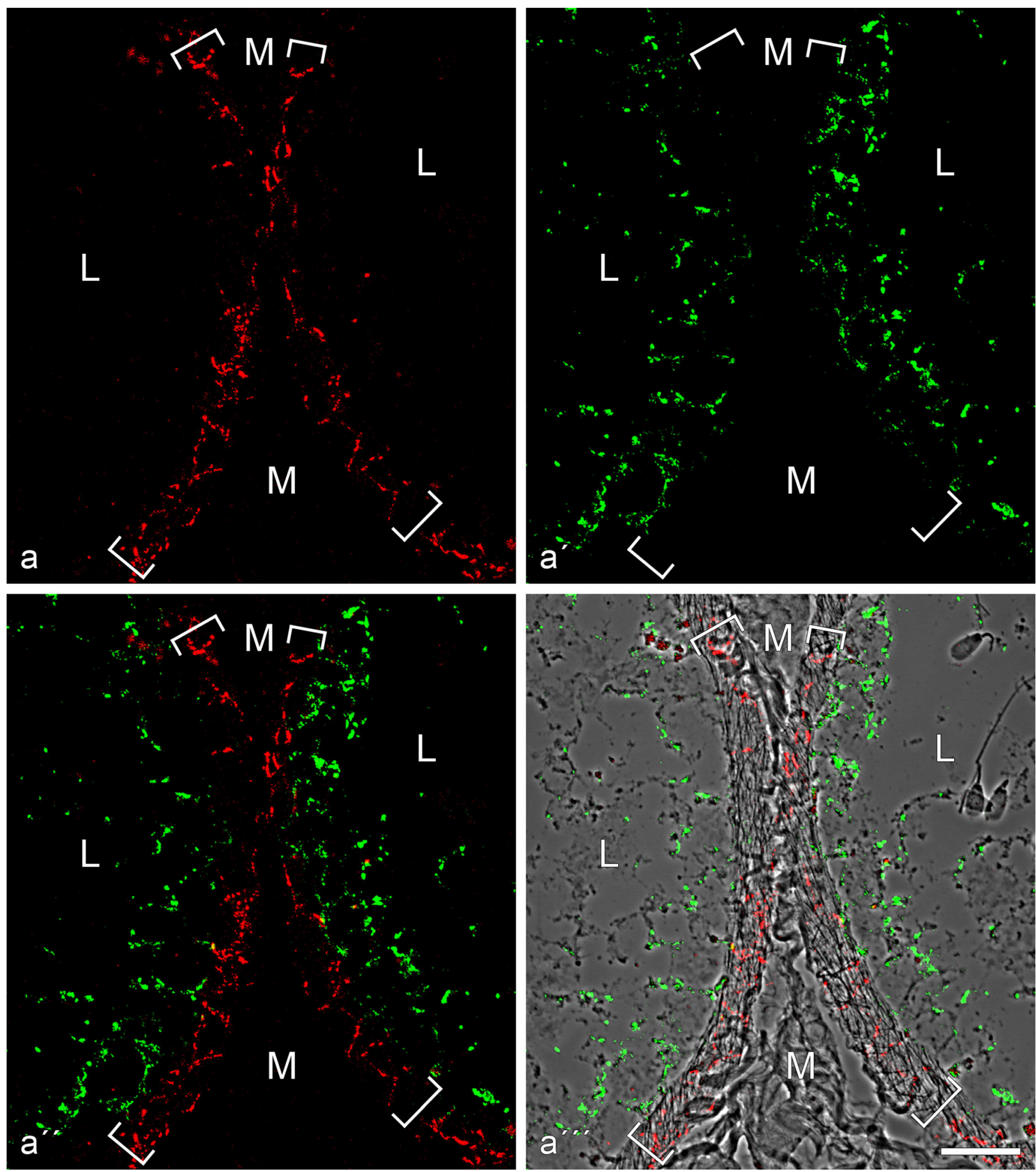

Fig. 4 Double-label immunofluorescence microscopy of cryostat crosssections through tubuli seminiferi of frozen bull testis after reactions with antibodies against E-cadherin (red; $\left.\mathbf{a}, \mathbf{a}^{\prime \prime}, \mathbf{a}^{\prime \prime \prime}\right)$ and N-cadherin (green; $\mathbf{a}^{\prime}$, $\left.\mathbf{a}^{\prime \prime}, \mathbf{a}^{\prime \prime \prime}\right)$. In $\mathbf{a}^{\prime \prime}$, the reactions are shown on a phase contrast background. Note the mutually exclusive immunostaining of cell-cell junctions of the adherens type, N-cadherin-based ones (green) in the Sertoli cells and

spermatogonia of the tubuli seminiferi and E-cadherin-containing junctions exclusively in a special layer of myoid cells surrounding the tubuli (demarcated by the parentheses). $M$ mesenchymal region with interstitial cells; $L$ lumen of the seminiferous tubules, with individual spermatids (e.g., on the right-hand side of a"'). Bar $20 \mu \mathrm{m}$ 

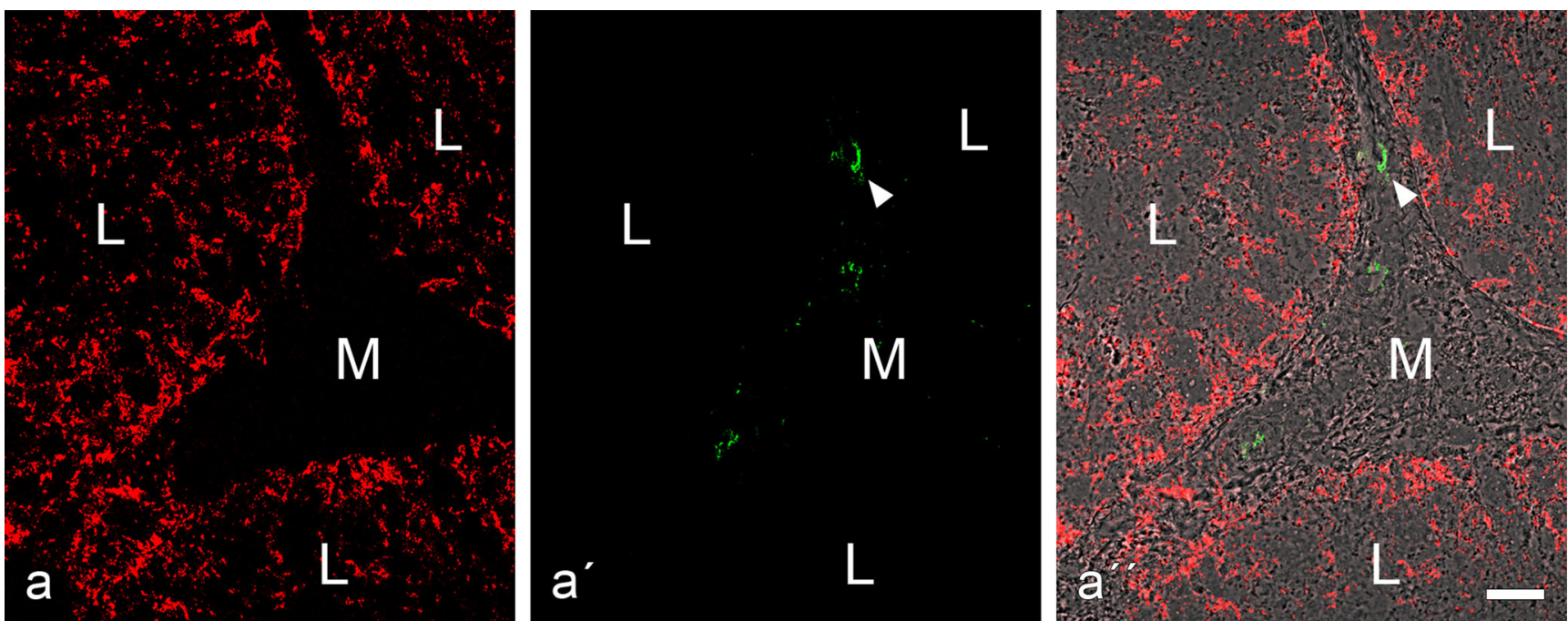

Fig. 5 Double-label immunofluorescence microscopy showing the reactions of antibodies to N-cadherin (a, red, mouse mAb) and desmoplakin (b, green, guinea pig antibodies) on a cross-section through tubuli seminiferi of bull testis ( $L$, tubular lumen; $M$, mesenchymal space). While the $\mathrm{N}$-cadherin reaction identifies the AJs of the Sertoli and

luminal space. On the other hand, during development and maturation, they have changed their molecular character as they have lost all keratin IFs and possess abundant bundles of vimentin IFs. They have also lost the typical epithelial junction architecture and instead are connected to each other and to the interspersed spermatogenic cells by a wealth of special and rather extended forms of adherens junctions.

Absence of desmosomes and desmosome-specific molecules

One of the clearest and most important results of our study is the demonstration that the mature tubuli seminiferi of all five mammalian species examined do not contain any desmosome structures (maculae adhaerentes in the morphological definition of Farquhar and Palade 1963). Neither do they possess any of the desmosome-specific cadherins, i.e., desmogleins and desmocollins, nor any of the desmosomespecific cytoplasmic plaque proteins, i.e., desmoplakin or one of the plakophilins Pkp1-3. In contrast, plakoglobin as a protein component of plaques of both desmosomes and adherens junctions (AJs; cf., e.g., Cowin et al. 1986; Franke et al. 1987, 2009) is also found in AJs of Sertoli cells. So, in Sertoli and spermatogonial cells, there are no desmosome-like structures or related junctions with desmosome-typical molecules.

The significance of the absence of desmosomes and even of any desmosome-specific molecules in junctions connecting Sertoli cells with each other or with spermatogenic cells is also based on direct experimental comparisons with their abundant presence in all portions of the excurrent duct epithelia (see also, e.g., Table 2). So we hope that, from now on, words such as "desmosomes", "desmosome-like structures" or spermatogonial cell layer (a and a" show the reaction in the three neighbouring tubular structures) there is no desmoplakin reaction $\left(\mathbf{a}^{\prime}\right.$; for a visualization "control" this picture has been selected as, accidentally, a very small artifical green particle is seen here, denoted by a white arrowhead). Bar $20 \mu \mathrm{m}$

"desmosomal proteins" will no longer appear in the literature on mature Sertoli cells (the need for this sentence is evident from Table 1 and Electronic Supplementary Material, Table S1), although the similar conclusion of Pelletier and Byers in 1992 ("Therefore, the term desmosome-like is seemingly inappropriate to designate these junctions...") has already been widely ignored by researchers in this field.

Of course, we are aware of the fundamental controversy of our present report and the recent articles of several other authors (see Table 1 and Electronic Supplementary Material, Table S1), in particular the publication of Lie et al. (2010). These authors have specifically claimed, based on experiments at the mRNA (RT-PCR) and protein or glycoprotein (immunoblots and immunolocalization) level, that Sertoli cells of rats contain desmogleins Dsg-1, Dsg-2 and Dsg-4, desmocollins Dsc-1 and Dsc-3 and plakophilins Pkp-1, Pkp-2, and Pkp-4, as well as desmoplakin. While the mentioning of "plakophilin-4" as a desmosomal component is obsolete since it has been demonstrated that this plaque protein does not occur in any kind of desmosome but, as "protein p0071", is restricted to AJs (Hofmann et al. 2008, 2009). In addition, the reported discovery of desmoglein Dsg-4 is highly disturbing as this glycoprotein has so far been identified only in the uppermost layers of the epidermis and in certain hair follicle layers (for references, see, e.g., Godsel et al. 2004; Schmidt and Koch 2008). However, as many of the claims reported by Lie et al. (2010) specifically address Sertoli cell cultures, a detailed critical discussion will have to be postponed to a future article in our series, which will deal with cell cultures and tumors assumed to be derived from Sertoli cells. 

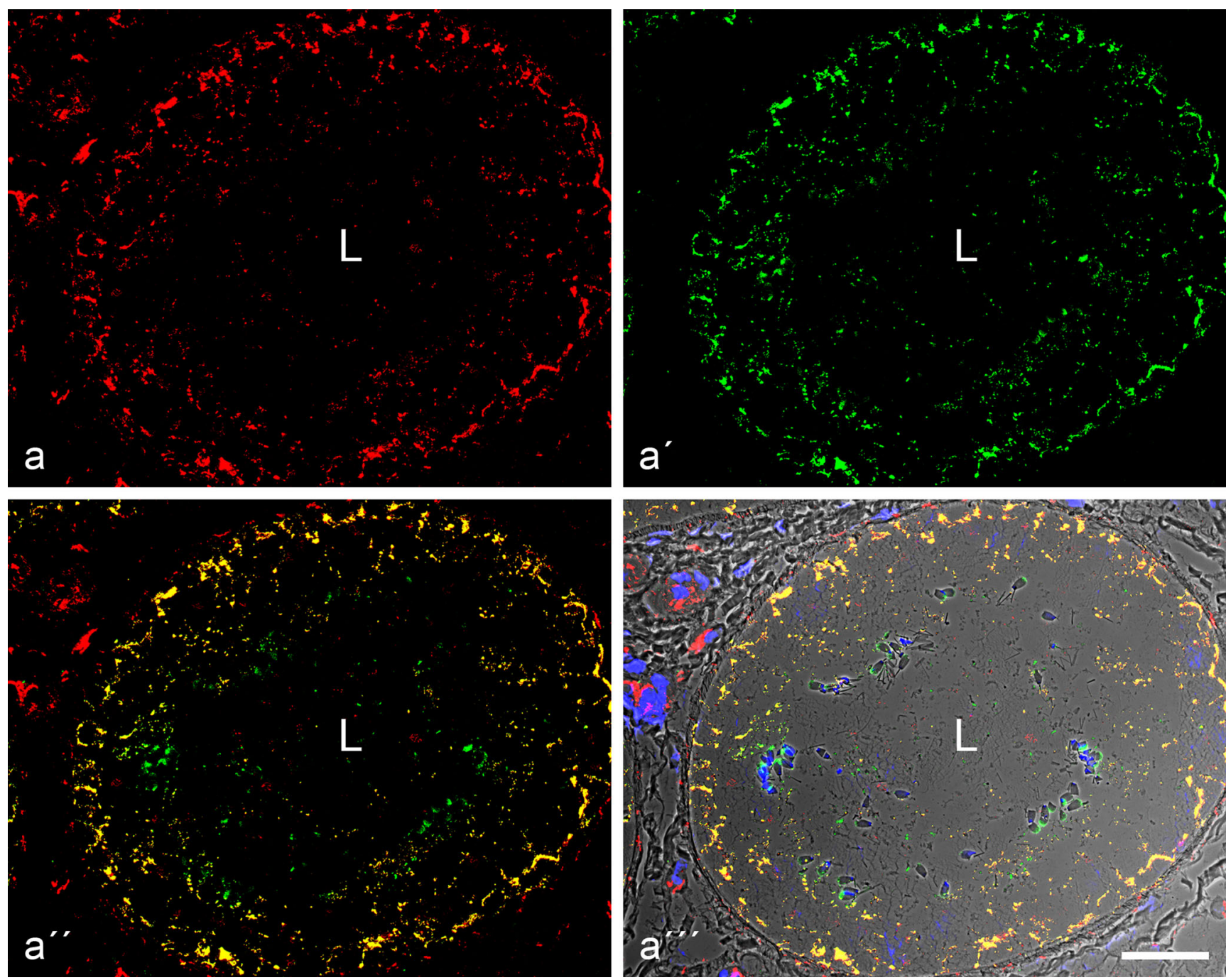

Fig. 6 Double-label immunofluorescence microscopy of cross-sections through seminiferous tubules of frozen bull testis, showing the nearcomplete colocalization of $\beta$-catenin (a, red, mouse $\mathrm{mAb}$ ) and $\mathrm{N}$ cadherin ( $\mathbf{a}^{\prime}$, green, rabbit antibodies) in the AJs of the Sertoli cell layer

On the other hand, in this context, we do not forget to mention the specific occurrences of individual desmosomal molecules in other ensembles such as desmoplakin in the complexus adhaerentes of parts of lymphatic endothelia (Schmelz and Franke 1993; Hämmerling et al. 2006; Moll et al. 2009), plakophilin Pkp-2 in AJs of certain very proliferative stages of mesenchymal cells (e.g., Barth et al. 2009, 2012; Rickelt et al. 2010; Rickelt 2012) and the "free" Dsg-2 glycoproteins dispersed on the surfaces of certain types of melanoma cells (Schmitt et al. 2007; Rickelt et al. 2008). Particularly complex "hybrid junctions" are the composite junctions (areae compositae) connecting mammalian cardiomyocytes (Franke et al. 2006) and the "meningioma junctions" in which E- or Ncadherin can be associated not only with $\alpha$ - and $\beta$-catenin, plakoglobin and protein p120 but also with the "desmosomal protein", plakophilin Pkp-2 (Akat et al. 2008).

of the tubules, demonstrated by the yellow merged colour (a", a"'; the latter is presented on a phase contrast background and with nuclei stained blue with DAPI). Note also $\beta$-catenin-positive structures in several types of interstitial cells. $L$, lumen. Bar $50 \mu \mathrm{m}$

The absence of desmosomes and any desmosome-specific molecules in mature Sertoli cells is also remarkable as these structures and molecules are present in stages of embryogenesis, fetal as well as early postnatal development, upon advanced aging and in various pathological situations and also in Sertolitype cells of a wide variety of non-mammalian vertebrates (for references, see Baccetti et al. 1983; Bergmann et al. 1984; Pfeiffer and Vogl 2002).

Like keratin IF bundles, vimentin IF bundles can also be anchored at desmosomal plaques (e.g., Kartenbeck et al. 1984; Schwechheimer et al. 1984; Moll et al. 1986; for references, see Franke et al. 2009). As desmosomes are absent in mature Sertoli cells, it is thus noteworthy that the abundantly present vimentin IF bundles are not anchored at - nor in any other way firmly attached to - the plaques of the diverse subtypes of AJs aforementioned (see, e.g., Electronic Supplementary Material, 

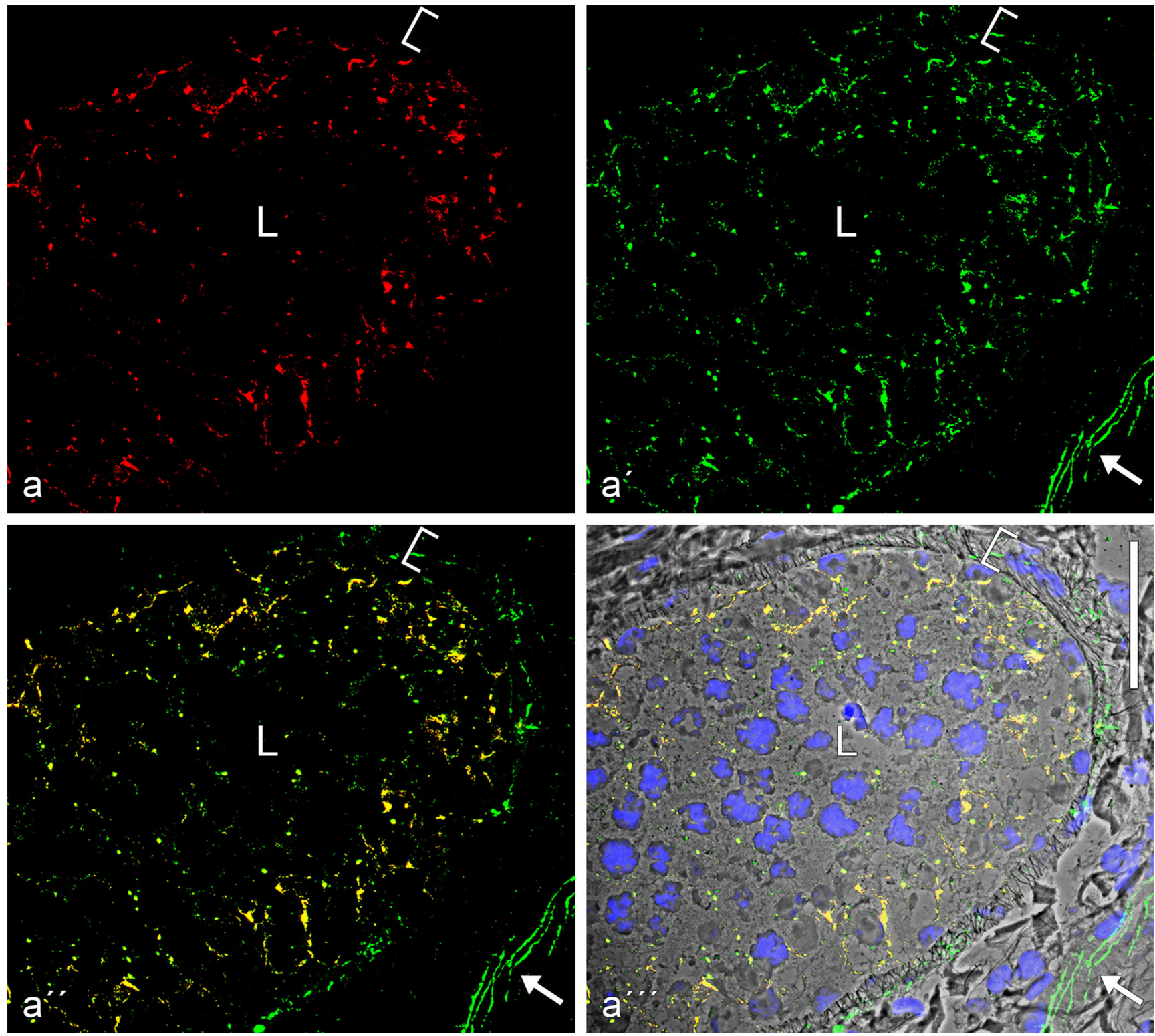

Fig. 7 Double-label immunofluorescence microscopy of cross-sections through seminiferous tubules of frozen bull testis, showing the nearcomplete colocalization of N-cadherin (a, red, mouse $\mathrm{mAb}$ ) and the plaque protein p0071 (a', green, guinea pig antibodies) in the AJs of the Sertoli cells, demonstrated by the yellow merger colour (a", a"'; the

latter is shown on a phase contrast background and with DAPI-staining of nuclei). Note also the intensive green immunostaining of the p0071 reaction in the junctions connecting endothelial cells in blood and lymph vessels (here indicated, e.g., by the arrow in the lower right-hand corner of $\left.\mathbf{a}^{\prime}-\mathbf{a}^{\prime \prime \prime}\right)$. $L$, lumen. Bar $50 \mu \mathrm{m}$

Fig. S6). The same seems to be true for the neurofilament bundles (see also Davidoff et al. 1999).

The various forms of AJs in the mammalian tubuli seminiferi, including the areae adhaerentes

Since the classic report by Farquhar and Palade (1963), the non-desmosomal adhering junctions, the adherens junctions (AJs), of epithelia have been found to occur in one of three morphological forms, the zonula adhaerens, the fascia adhaerens and the punctum adhaerens. Clearly, structures of the two latter types also exist in both the tubuli seminiferi and

the excurrent duct epithelia, the excurrent ducts also having typical subapical zonulae adhaerentes (see also Figs. 1, 2, 3). In addition to these three forms, we now define a fourth major form, the areae adhaerentes, i.e., extended, often very large surface regions (e.g., including areas larger than $30 \mu \mathrm{m}^{2}$ as determined from serial sections), which obviously provide very important structures of monolayer organization in the seminiferous tubules, both in homotypic AJs and in heterotypic connections with spermatogenic cells. As this study shows, they generally contain $\mathrm{N}$-cadherin and the typical AJ plaque ensemble of proteins (Table 2). Whether such extended regions of the AJ type also occur in $\mathrm{N}$ - 

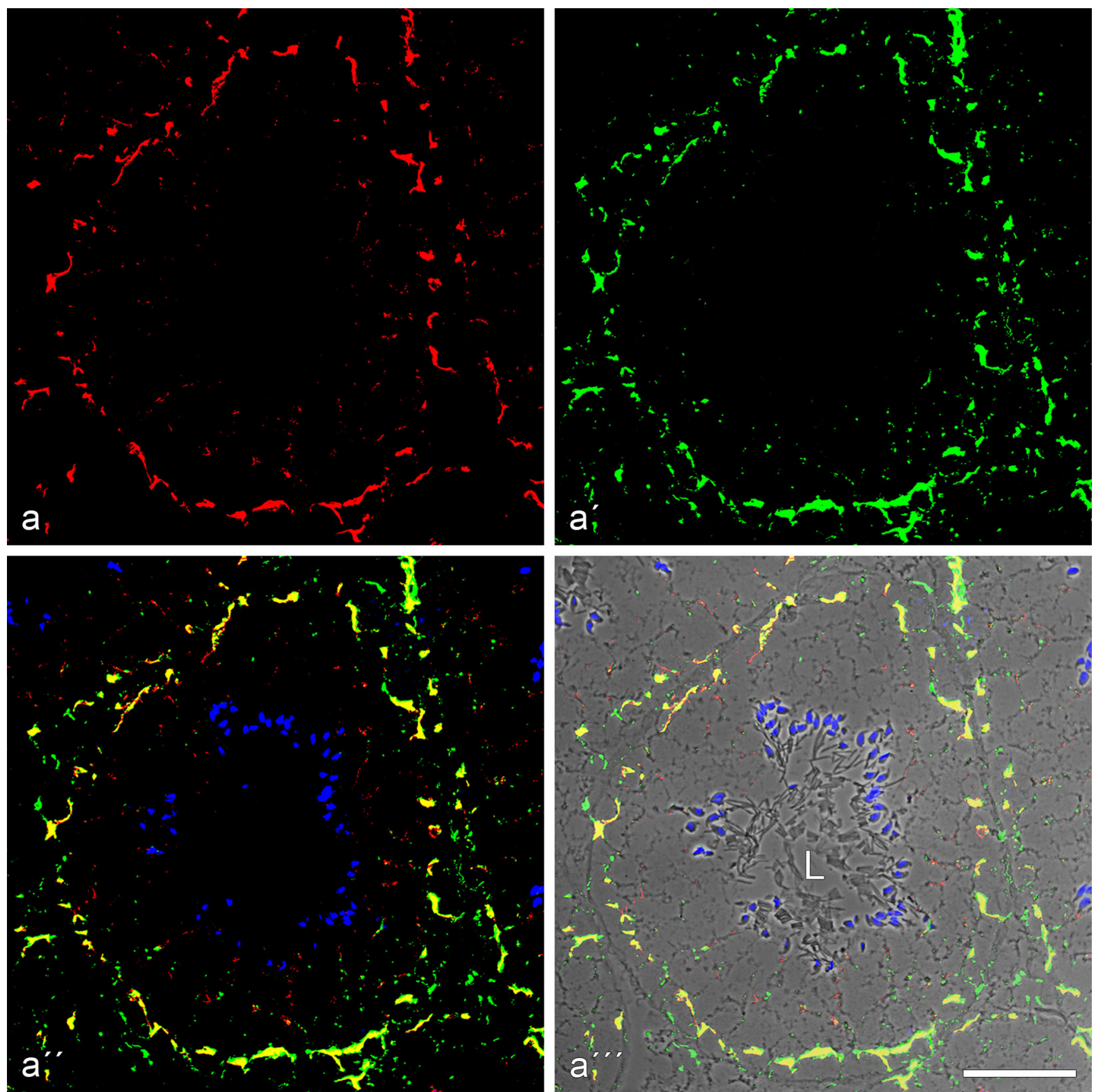

Fig. 8 Double-label immunofluorescence microscopy of a cross-section through a seminiferous tubule of frozen mouse testis tissues, showing the very frequent colocalization of the plaque protein of the striatin family (a, red, mouse $\mathrm{mAb}$ ) and $\beta$-catenin ( $\mathbf{a}^{\prime}$, green, rabbit antibodies) in the basal parts of Sertoli cells and in spermatogonial cells, demonstrated by the

yellow merger colour (a", $\mathbf{a}^{\prime \prime}$; the latter is shown on a phase contrast background and with DAPI-staining of the nuclei). Note also the DAPIstained elongated spermatid heads typical for rodents. $L$, lumen of the seminiferous tubules. Bar $50 \mu \mathrm{m}$

cadherin-based cell-cell contacts of other cells cannot yet be stated.

Morphologically, one can distinguish three major subforms of AJ structures in the seminiferous tubules (for diverse morphological AJ subtypes; see also fig. 28.1 of Pelletier 2001): One subform (type I) with a relatively thick and dense cytoplasmic plaque (e.g., Fig. 10d-d"'), a second subform (type II) with less and only loosely associated filamentous plaque substructures (e.g., Figs. 9d, 10a-c) and a third subform (type III) with very little and very thin cytoplasmic plaque filaments (MPM-AJs), which even in electron micrographs are often not distinctly resolved (e.g., Figs. 9, 10a-d, 11i-e). In certain areas of cell-cell contacts, diverse AJ subtypes may occur side by, side, often alternating or group-wise 


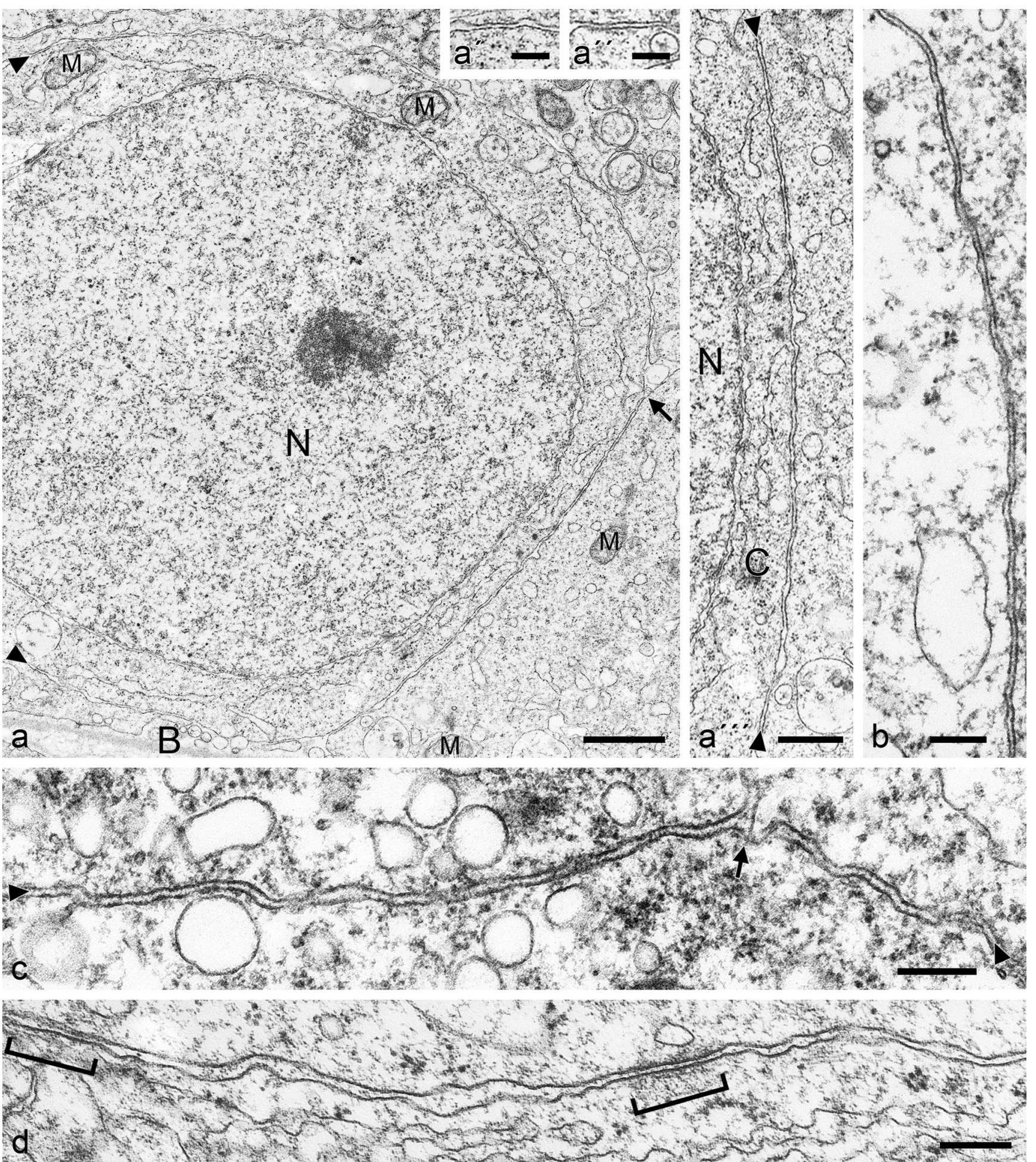

Fig. 9 Electron micrographs of ultrathin sections through seminiferous tubules of boar $\left(\mathbf{a}-\mathbf{a}^{\prime \prime \prime}\right)$ and bull (b-d) testis, showing a survey picture including large parts of a nucleus $(N)$ and details of the very extended, rather regularly narrow-spaced (membrane-to-membrane interspace $8-18 \mathrm{~nm}$ ) area adhaerens junctions; $B$, basal lamina; $M$, mitochondrion (a'-a'"' present details at higher magnification; $C$, cytoplasm). Such extended, narrow-spaced plasma membrane connections of the "minimal plaque material" AJ type are also seen in bovine Sertoli cells (b-d) and only occasionally rather thin, loosely and irregularly arranged plaque-like structures are detected (see, e.g., d, parentheses). Note that these MPM-AJ associations are also maintained at sites where the plasma membranes of three cells meet (c, arrow). Bars (a) $1 \mu \mathrm{m},\left(\mathbf{a}^{\prime \prime \prime}\right) 500 \mathrm{~nm},\left(\mathbf{a}^{\prime}, \mathbf{a}^{\prime \prime}, \mathbf{b}-\mathbf{d}\right) 200 \mathrm{~nm}$ 


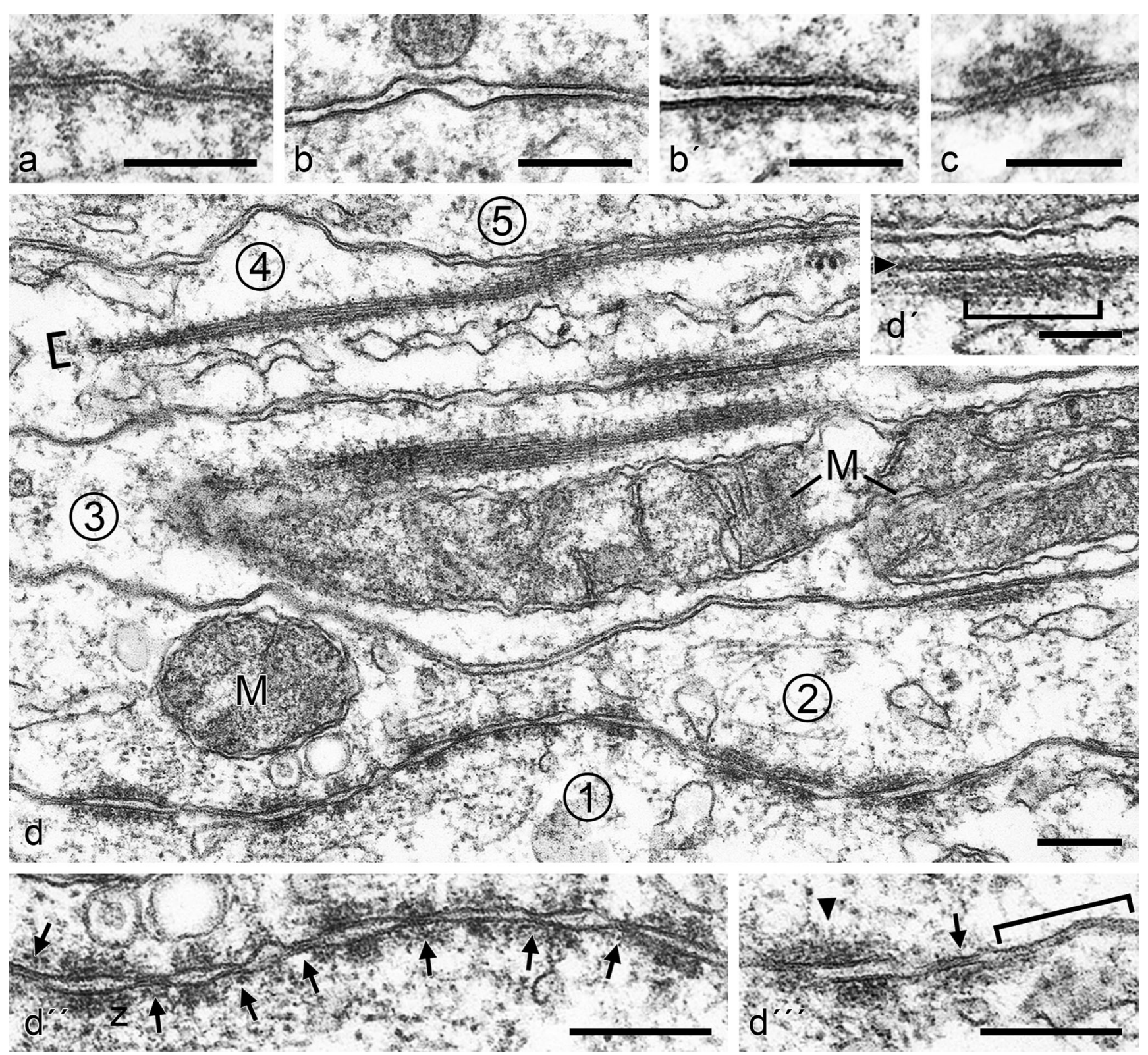

Fig. 10 Electron micrographs of ultrathin sections through testicular tissue of a bull, showing various subtypes and aspects of AJs connecting Sertoli cells in the tubuli seminiferi. a Junctions characterized by a rather narrow distance between the membrane profiles $(8-18 \mathrm{~nm})$ loosely associated with some cytoplasmic plaque material that is highly variable in size and configuration. b, b' Overview (b) and partial magnification ( $\left.\mathbf{b}^{\prime}\right)$ of a region containing an $\mathrm{AJ}$ with a strictly planar arrangement of 6- to 7$\mathrm{nm}$-thick membranes, an intermembrane space of $8-18 \mathrm{~nm}$, with serially arranged "punctate midline" granules of 2-5 nm diameter $\left(\mathbf{b}^{\prime}\right)$ and a general but loose cytoplasmic plaque coverage. $\mathbf{c}$ This small and rather narrow junction (ca. $5 \mathrm{~nm}$ intermembrane distance) is covered asymmetrically with irregularly shaped cytoplasmic plaque material. d Survey micrograph showing five tight-packed Sertoli cell processes and extended cell-cell contact regions (areae adhaerentes) between 5 pairs of cells (numbered 1-5). Note in these Sertoli cell processes, the dense package of, e.g., mitochondria $(M)$ and the so-called "ectoplasmic specializations", i.e., cortical paracrystalline actin microfilament bundles that in some regions are parallel to - and rather closely associated with - cell-cell junction plasma membrane regions, often revealing lateral up to 4-nmthick cross-bridges between the filament paracrystals and the plasma membrane (see, e.g., the bundle in the upper right of cell process numbered 2 and the parenthesis in the insert labeled $\mathbf{d}^{\prime}$ ). Note also the extended region with cell-cell junctions of the MPM-AJ type connecting cells numbered 1 and 2 in (d) (with higher partial magnifications in $\mathbf{d}^{\prime \prime}$ and $\mathbf{d}^{\prime \prime \prime)}$, showing numerous, closely spaced, dense arrangements of typical AJs with cytoplasmic plaque material separated by tight-adpressed special junctions of 10-30 nm diameter (arrows in $\mathbf{d}^{\prime \prime}, \mathbf{d}^{\prime \prime}$ ). All three major junction types are seen side-by-side in (d"'): a punctum adhaerens (arrowhead), a tightly adpressed membrane junction (arrow) and a region of the MPM-AJ type (parenthesis; cf. Fig. 10). Bars (a, b, d, d", d"') $200 \mathrm{~nm},\left(\mathbf{b}^{\prime}, \mathbf{c}, \mathbf{d}^{\prime}\right) 100 \mathrm{~nm}$ 


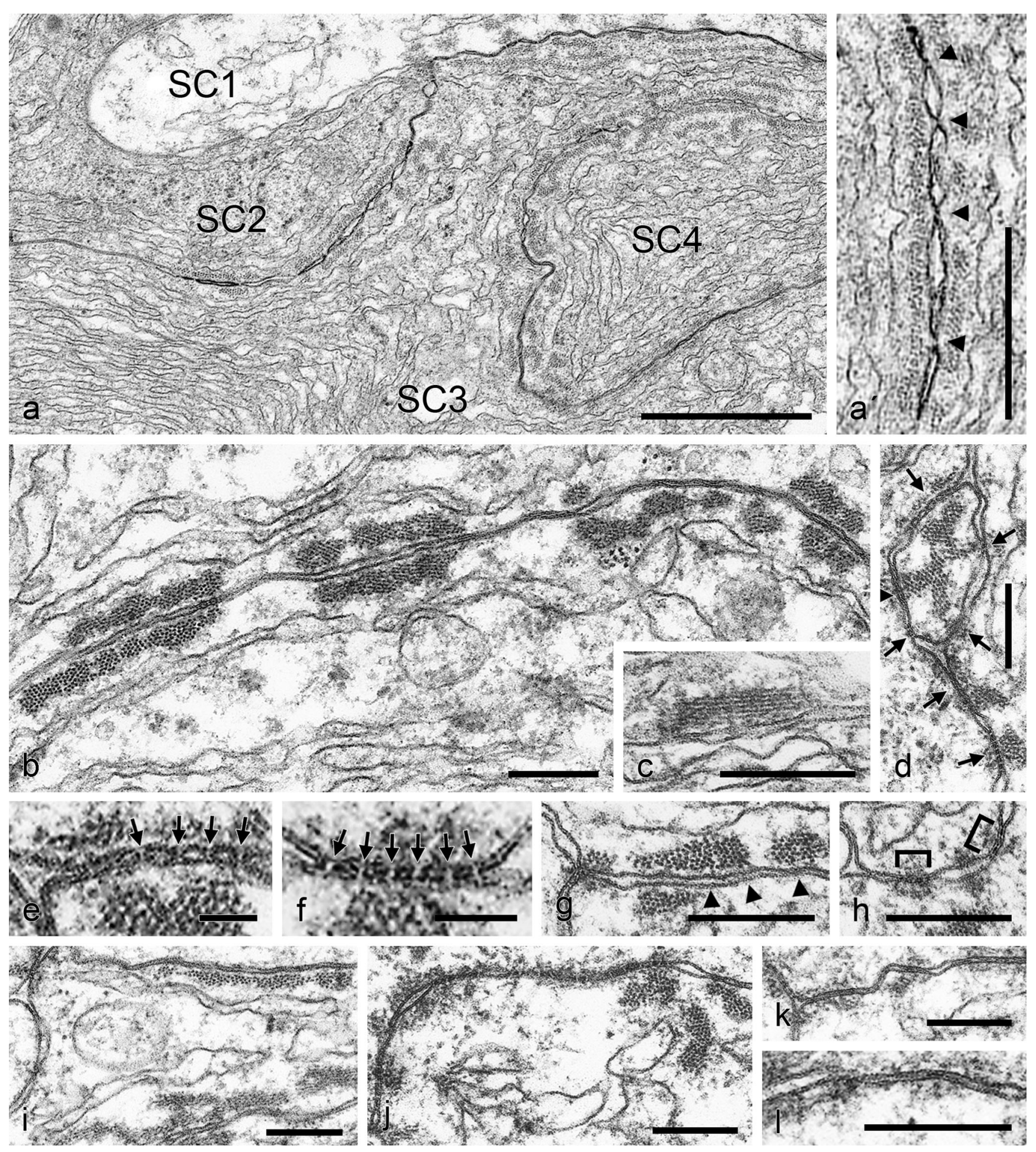

interspersed (e.g., Fig. 10d"'). These different AJ subforms also occur in the seminiferous tubules of many other mammalian species (see in particular Pelletier 1988, 2001; Pelletier and Byers 1992).

From a series of observations in the neuronal system, it may also be hypothesized that, in the seminiferous tubules, Ncadherin has in addition a developmental biological role in topogenesis and specific cell-cell interactions, including the local stabilization of other cell-cell connection structures, as it has first been proposed for certain synapses (e.g., Ushida et al. 1996; Arikkath 2010; Mendez et al. 2010; Tan et al. 2010; Gärtner et al. $2012 \mathrm{a}, \mathrm{b})$. Whether such roles and interactions can also be ascribed to some of the various subtypes of the N-cadherinbased junctional structures of the testis remains to be examined. 
4 Fig. 11 Electron micrographs of ultrathin sections through bovine testicular tissue, showing details of adherens regions (areae adhaerentes) and cribelliform junctions connecting Sertoli cells of a specific subtype. Sertoli cells of this subtype are characterized by a high packing density of endoplasmic reticulum cisternae in a cytoplasm of marked electron density and with extended regions of cell-cell junctions of the adherens type as well as some rather small cribelliform junctions and frequent junctionassociated, paracrystalline actin microfilament bundles ("ectoplasmic specializations"). a Interdigitating processes of Sertoli cells (SC1-SC4) are connected by extended plasma membrane regions of "normal" intermembrane distance AJs, interspersed with small tightly adpressed membrane junctions some of which even suggest direct molecular interaction $\left(\mathbf{a}^{\prime}, \mathbf{b}, \mathbf{d}\right)$. Distinct narrow channels between the cytoplasms of two Sertoli cells are indeed resolved in some very thin sections and appear as sieve-plate junctions (some positions are denoted by arrows in $\mathbf{d}$ and some of them are shown at higher magnification in $\mathbf{e}$ and $\mathbf{f}$ ): cribelliform junctions (areae cribelliformes; $\mathbf{e}, \mathbf{f}$ ). The channel-like cell-cell continuities of these cribelliform junctions (e, f) have an inner "pore" diameter of 6$7 \mathrm{~nm}$ and a total length of $6-9 \mathrm{~nm}$. Note that these cell-cell channels are often also characterized by electron-dense, plaque-like structures on one or on both sides of the channel (arrowheads or brackets in $\mathbf{d}, \mathbf{f}, \mathbf{h}, \mathbf{j}$ ). All in all, a major part of the plasma membrane indicates a junction-like association with adjacent actin filament bundles, which are often cross-bridged to the plasma membrane by short structures (c, $\mathbf{g}, \mathbf{i}, \mathbf{j}$; see also arrowheads in $\mathbf{g}$ ). Not infrequently, these parallel and close-spaced membrane-membrane junction-like structures are coated with loose and irregularly shaped cytoplasmic dense materials (j-I). Bars (a) $1 \mu \mathrm{m},\left(\mathbf{a}^{\prime}\right) 500 \mathrm{~nm},(\mathbf{b}-\mathbf{d}, \mathbf{g}-\mathbf{l})$ $200 \mathrm{~nm},(\mathbf{e}, \mathbf{f}) 50 \mathrm{~nm}$

\section{Cribelliform junctions}

With great surprise, we noticed, amidst the AJs of Sertoli cells, a further distinct and totally novel kind of cell-cell junction structure that is characterized by clusters of channel-like, ca. 6- to 7-nm-wide cytoplasmic continuity between adjacent Sertoli cells, i.e., pore structures formed by the fused plasma membranes of both cells. As we have shown, these sieve- plate-like, close-spaced assemblies of channels, areae cribelliformes, occur as small, distinct groups of cell-cell continuities that would allow the passage of relatively large molecules or particles. At present, we cannot answer questions as to their frequencies and functions or whether they contain any specific molecules, questions that we are currently trying to answer in quantitative and morphometric studies. Moreover, we will have to demonstrate the cell-to-cell passages of fluorescent or electron microscopic markers between Sertoli cells and determine the nature and sizes of molecules and particles that can take that route.

Of course, the question arises why these cribelliform junctions with their characteristic cytoplasmic sieve pore structures between Sertoli cells have not been described before. Here, however, careful examination of the published electron micrographs has revealed a few illustrations in works on guinea pig and dog seminiferous epithelia that show structures suggestive of such groups of cribelliform connections (see, e.g., figs. 3 and 4 of Connell 1978, or figs. 7 and 17 in Pelletier and Friend 1983). Thus, we expect that such junctions will be detectable in the Sertoli cells of diverse mammalian species.

\section{Concluding remarks}

Our findings confirm and extend the view that the Sertoli cells of mature tubuli seminiferi and their cell-cell junction system represent a special and complex epithelial system, profoundly different from those of all other epithelial cells: Keratins are lost, desmosomal structures and desmosome-typical molecules are lost, E-cadherin is lost, EpCAM-containing junctions are lost. Instead, various subtypes of other adhaerens

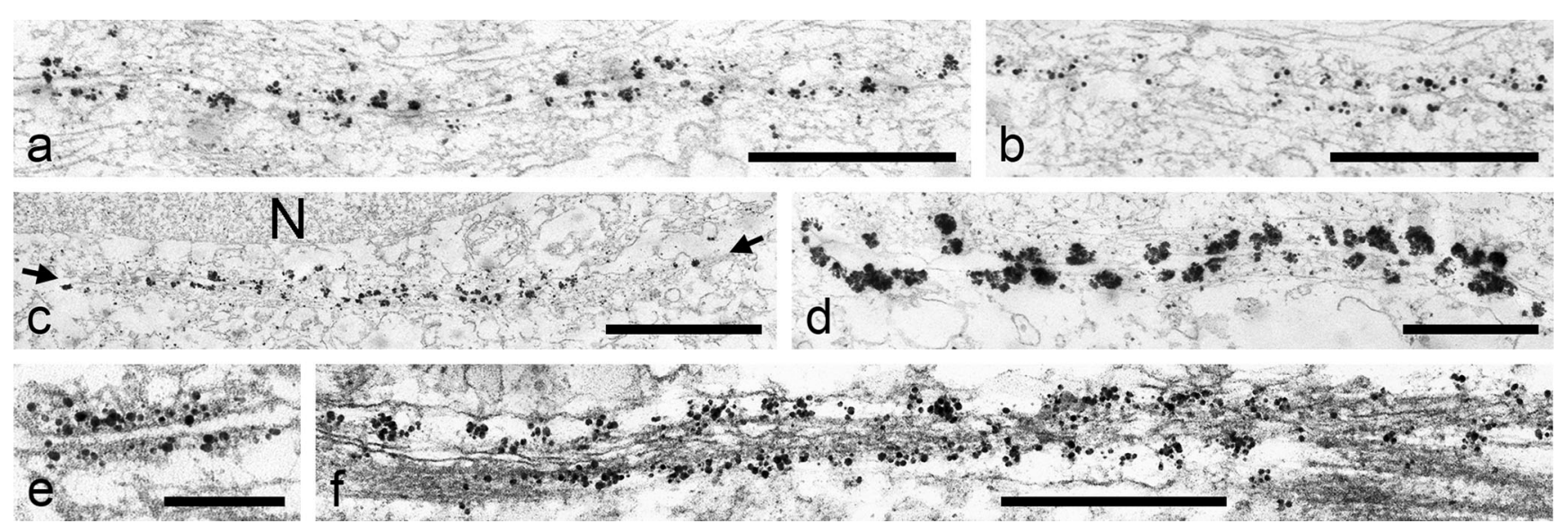

Fig. 12 Immunoelectron microscopy of bull testicular tissue using antibodies against $\beta$-catenin (a-d), N-cadherin (e) and striatin (f). The silverenhanced immunogold grains show specific binding of $\beta$-catenin in the extended regions of these Sertoli cell contacts with neighboring cells, including very long $(4-6 \mu \mathrm{m})$ stretches with almost continuous $\beta$-catenin labelling (a-d). The reaction antibodies used in the preparation (d) have been enlarged by an especially intensive silver enhancement. All the diverse morphological subforms of Sertoli-Sertoli cell junctions also appear positive for N-cadherin (e.g., e) as well as for the other major adherens plaque proteins such as striatin (f) $\operatorname{Bars}(\mathbf{c}) 1 \mu \mathrm{m},(\mathbf{d}, \mathbf{f}) 500 \mathrm{~nm}$, $(\mathbf{a}, \mathbf{b}, \mathbf{e}) 200 \mathrm{~nm}$ 
structures have formed that are based on N-cadherin. While such a transition from $\mathrm{E}$ - to N-cadherin is known from other cell-type changes in embryonal and fetal development as well as from certain pathological transformations as in the invasion and metastasis of diverse kinds of tumor cells (for review, see, e.g., Kalluri and Weinberg 2009), another form of advent of $\mathrm{N}$-cadherin in epithelial cells, i.e., the formation of AJs based on E-N heterodimer clusters, as described for mammalian hepatocytes and liver tumor cells in situ and in culture (Straub et al. 2011), seems to be excluded from the mature and active Sertoli cells.

Acknowledgments We wish to thank Dr. Michael Rogers (German Cancer Research Center) for reading and correcting the English text and Eva Gundel for careful assembly of the manuscript text.

This work was supported by a grant from the German-Israeli Foundation for Scientific Research and Development (GIF grant I-1098-43.11/ 2010). A major part of this work has been presented as a Bachelor thesis of the first author (Brandenburg University of Technology, Senftenberg, 2013).

Open Access This article is distributed under the terms of the Creative Commons Attribution License, which permits any use, distribution and reproduction in any medium, provided the original author(s) and the source are credited.

\section{References}

Akat K, Bleck CKE, Lee Y-MA, Haselmann-Weiss U, Kartenbeck J (2008) Characterization of a novel type of adherens junction in meningiomas and the derived cell line HBL-52. Cell Tissue Res $331: 401-412$

Altorfer J, Fukuda T, Hedinger C (1974) Desmosomes in human seminiferous epithelium. An electron microscopic study. Virchows Arch B 16:181-194

Arikkath J (2010) N-cadherin: stabilizing synapses. J Cell Biol 189: 397-398

Baccetti B, Bigliardi E, Talluri MV, Burrini AG (1983) The Sertoli cell in lizards. J Ultrastruct Res 85:11-23

Barth M, Schumacher H, Kuhn C, Akhyari P, Lichtenberg A, Franke WW (2009) Cordial connections: molecular ensembles and structures of adhering junctions connecting interstitial cells of cardiac valves in situ and in cell culture. Cell Tissue Res 337:63-77

Barth M, Rickelt S, Noffz E, Winter-Simanowski S, Niemann H, Akhyari P, Lichtenberg A, Franke WW (2012) The adhering junctions of valvular interstitial cells: molecular composition in fetal and adult hearts and the comings and goings of plakophilin-2 in situ, in cell culture and upon re-association with scaffolds. Cell Tissue Res 348: 295-307

Bergmann M, Schindelmeiser J, Greven H (1984) The blood-testis barrier in vertebrates having different testicular organization. Cell Tissue Res 238:145-150

Byers S, Graham R, Dai HN, Hoxter B (1991) Development of Sertoli cell junctional specializations and the distribution of the tightjunction-associated protein $\mathrm{ZO}-1$ in the mouse testis. Am J Anat $191: 35-47$
Byers SW, Sujarit S, Jegou B, Butz S, Hoschutzky H, Herrenknecht K, MacCalman C, Blaschuk OW (1994) Cadherins and cadherinassociated molecules in the developing and maturing rat testis. Endocrinology 134:630-639

Cheng CY, Mruk DD (2002) Cell junction dynamcis in the testis: Sertoligerm cell interactions and male contraceptive development. Physiol Rev 82:825-874

Cheng CY, Mruk DD (2011) Regulation of spermiogenesis, spermiation and blood-testis barrier dynamics: novel insights from studies on Eps8 and Arp3. Biochem J 435:553-562

Cheng CY, Mruk DD (2012) The blood-testis barrier and its implications for male contraception. Pharmacol Rev 64:16-64

Cheng CY, Wong EWP, Lie PPY, Li MWM, Mruk DD, Yan HHN, Mok D-W, Mannu J, Mathur PP, W-y L, Bonanomi M, Silvestrini B (2011) Regulation of blood-testis barrier dynamics by desmosome, gap junction, hemidesmosome and polarity proteins. An unexpected turn of events. Spermatogenesis 1:105-115

Connell CJ (1978) A freeze-fracture and lanthanum tracer study of the complex junction between Sertoli cells of the canine testis. J Cell Biol 76:57-75

Cowin P, Kapprell H-P, Franke WW, Tamkun J, Hynes RO (1986) Plakoglobin: a protein common to different kinds of intercellular adhering junctions. Cell 46:1063-1073

Cyr DG, Blaschuk OW, Robaire B (1992) Identification and developmental regulation of cadherin messenger ribonucleic acids in the rat testis. Endocrinology 131:139-145

Cyr DG, Hermo L, Robaire B (1993) Developmental changes in epithelial cadherin messenger ribonucleic acid and immunocytochemical localization of epithelial cadherin during postnatal epididymal development in the rat. Endocrinology 132: $1115-1124$

Cyr DG, Robaire B, Hermo L (1995) Structure and turnover of junctional complexes between principal cells of the rat epididymis. Microsc Res Tech 30:54-66

Cyr DG, Gregory M, Dubé E, Dufresne J, Chan PTK, Hermo L (2007) Orchestration of occludins, claudins, catenins and cadherins as players involved in maintenance of the blood-epididymal barrier in animals and humans. Asian J Androl 9:463-475

Davidoff MS, Middendorff R, Pusch W, Müller D, Wichers S, Holstein AF (1999) Sertoli and Leydig cells of the human testis express neurofilament triplet proteins. Histochem Cell Biol 111:173-87

DeBellefeuille S, Hermo L, Gregory M, Dufresne J, Cyr DG (2003) Catenins in the rat epididymis: their expression and regulation in adulthood and during postnatal development. Endocrinology 144: 5040-5049

Dym M (1974) The fine structure of monkey Sertoli cells in the transitional zone at the junction of the seminiferous tubules with the tubuli recti. Am J Anat 140:1-25

Dym M (1976) The mammalian rete testis - a morphological examination. Anat Rec 186:493-523

Dym M (1977) The male reproductive system. In: Weiss L, Greep RO (eds) Histology. McGraw-Hill, New York, pp 979-1038

Dym M, Fawcett DW (1970) The blood-testis barrier in the rat and the physiological compartmentation of the seminiferous epithelium. Biol Reprod 3:308-326

Farquhar MG, Palade GE (1963) Junctional complexes in various epithelia. J Cell Biol 17:375-412

Franke WW (2010) Discovering the molecular components of intercellular junctions-a historical view. In: Nelson J, Fuchs E (eds) Cold spring harbor perspectives in biology. Cell-Cell junctions. Vol 1. Cold Spring Harbor Laboratory, New York, pp 1-34

Franke WW, Grund C, Fink A, Weber K, Jockusch BM, Zentgraf H, Osborn M (1978) Location of actin in the microfilament bundles associated with the junctional specializations between Sertoli cells and spermatids. Biol Cell 31:7-14 
Franke WW, Grund C, Schmid E (1979) Intermediate-sized filaments present in Sertoli cells are of the vimentin type. Eur J Cell Biol 19: 269-275

Franke WW, Schmid E, Grund C, Müller H, Engelbrecht I, Moll R, Stadler J, Jarasch E-D (1981) Antibodies to high molecular weight polypeptides of desmosomes: specific localization of a class of junctional proteins in cells and tissues. Differentiation 20:217-241

Franke WW, Moll R, Schiller DL, Schmid E, Kartenbeck J, Müller H (1982) Desmoplakins of epithelial and myocardial desmosomes are immunologically and biochemically related. Differentiation 23: $115-127$

Franke WW, Moll R, Müller H, Schmid E, Kuhn C, Krepler R, Artlieb U, Denk H (1983) Immunocytochemical identification of epitheliumderived human tumors with antibodies to desmosomal plaque proteins. Proc Natl Acad Sci USA 80:543-547

Franke WW, Cowin P, Schmelz M, Kapprell H-P (1986) The desmosomal plaque and the cytoskeleton. In: Bock G, Clark S (eds) Junctional complexes of epithelial cells. Wiley, Chichester, pp 26-48

Franke WW, Kapprell H-P, Cowin P (1987) Immunolocalization of plakoglobin in endothelial junctions: identification as a special type of zonulae adhaerentes. Biol Cell 59:205-218

Franke WW, Jahn L, Knapp AC (1989) Cytokeratins and desmosomal proteins in certain epithelioid and nonepithelial cells. In: Osborn M, Weber K (eds) Cytoskeletal proteins in tumor diagnosis. Cold Spring Harbor Laboratories, Cold Spring Harbor, pp 151-172

Franke WW, Borrmann CM, Grund C, Pieperhoff S (2006) The area composita of adhering junctions connecting heart muscle cells of vertebrates. I. Molecular definition in intercalated disks of cardiomyocytes by immunoelectron microscopy of desmosomal proteins. Eur J Cell Biol 85:69-82

Franke WW, Rickelt S, Barth M, Pieperhoff S (2009) The junctions that don't fit the scheme: special symmetrical cell-cell junctions of their own kind. Cell Tissue Res 338:1-17

Franke WW, Heid H, Zimbelmann R, Kuhn C, Winter-Simanowski S, Dörflinger Y, Grund C, Rickelt S (2013) Transmembrane protein PERP is a component of tessellate junctions and of other junctional and non-junctional plasma membrane regions in diverse epithelial and epithelium-derived cells. Cell Tissue Res 353:99-115

Franke WW, Dörflinger Y, Kuhn C, Zimbelmann R, Winter-Simanowski S, Frey N, Heid H (2014) Protein LUMA is a cytoplasmic plaque constituent of various epithelial adherens junctions and the composite junctions of the myocardial intercalated disks: a unifying finding for cell biology and cardiology. Cell Tissue Res (In press)

Gärtner A, Fornasiero EF, Munck S, Vennekens K, Seuntjens E, Huttner WB, Valtorta F, Dotti CG (2012a) N-cadherin specifies first asymmetry in developing neurons. EMBO J 31(8):1893-1903

Gärtner A, Fornasiero EF, Dotti CG (2012b) N-cadherin: a new player in neuronal polarity. Cell Cycle 11:2223-2224

Godsel LM, Getsios S, Huen AC, Green KJ (2004) The molecular composition and function of desmosomes. In: Behrens J, Nelson WJ (eds) Cell adhesion. Vol 165. Springer, Berlin

Hämmerling B, Grund C, Boda-Heggemann J, Moll R, Franke WW (2006) The complexus adhaerens of mammalian lymphatic endothelia revisited: a junction even more complex than hitherto thought. Cell Tissue Res 324:55-67

Hofmann I, Kuhn C, Franke WW (2008) Protein p0071, a major plaque protein of non-desmosomal adhering junctions, is a selective celltype marker. Cell Tissue Res 334:381-399

Hofmann I, Schlechter T, Kuhn C, Hergt M, Franke WW (2009) Protein p0071-an armadillo plaque protein that characterizes a specific subtype of adherens junctions. J Cell Sci 122:21-24

Kalluri R, Weinberg RA (2009) The basics of epithelial-mesenchymal transition. J Clin Invest 119:1420-1428

Kartenbeck J, Schwechheimer K, Moll R, Franke WW (1984) Attachment of vimentin filaments to desmosomal plaques in human meningiomal cells and arachnoidal tissue. J Cell Biol 98:1072-1081
Kasper M, Stosiek P (1989) Immunohistochemical investigation of different cytokeratins and vimentin in the human epididymis from the fetal period up to adulthood. Cell Tissue Res 257:661-664

Kopera IA, Bilinska B, Cheng CY, Mruk DD (2010) Sertoli-germ cell junctions in the testis: a review of recent data. Philos Trans R Soc Lond B 365:1593-1605

Langbein L, Pape UF, Grund C, Kuhn C, Praetzel S, Moll I, Moll R, Franke WW (2003) Tight junction-related structures in the absence of a lumen: occludin, claudins and tight junction plaque proteins in densely packed cell formations of stratified epithelia and squamous cell carcinomas. Eur J Cell Biol 82:385-400

Lee NPY, Cheng CY (2004) Ectoplasmic specialization, a testis-specific cell-cell actin-based adherens junction type: is this a potential target for male contraceptive development? Hum Reprod Update 10: 349-369

Lee NPY, Wong EWP, Mruk DD, Cheng CY (2009) Testicular cell junction: a novel target for male contraception. Curr Med Chem 16:906-915

Li MWM, Mruk DD, Lee WM, Cheng CY (2009) Connexin 43 and plakophilin-2 as a protein complex that regulates blood-testis barrier dynamics. Proc Natl Acad Sci USA 106:10213-10218

Lie PPY, Cheng CY, Mruk DD (2010) Crosstalk between desmoglein-2/ desmocollin-2/Src kinase and coxsackie and adenovirus receptor/ ZO-1 protein complexes regulates blood-testis barrier dynamics. Int J Biochem Cell Biol 42:975-986

Lie PPY, Cheng CY, Mruk DD (2011) The biology of the desmosomelike junction: a versatile anchoring junction and signal transducer in the seminiferous epithelium. Int Rev Cell Mol Biol 286:223-269

Mendez P, De Roo M, Poglia L, Klauser P, Muller D (2010) N-cadherin mediates plasticity-induced long-term spine stabilization. J Cell Biol 189:589-600

Mertens C, Kuhn C, Franke WW (1996) Plakophilins 2a and 2b: constitutive proteins of dual location in the karyoplasm and the desmosomal plaque. J Cell Biol 135:1009-1025

Mok K-W, Lie PPY, Mruk DD, Mannu J, Mathur PP, Silvestrini B, Cheng CY (2012) The apical ectoplasmic specialization-blood-testis-barrier functional axis is a novel target for male contraception. Adv Exp Med Biol 763:334-355

Mok KW, Mruk DD, Cheng CY (2013a) Regulation of bloodtestis barrier (BTB) dynmics during spermatogenesis via the "Yin" and "Yang" effects of mammalian target of rapamycin complex 1 (mTORC1) and mTORC2. Int Rev Cell Mol Biol 301:291-358

Mok K-W, Mruk DD, Lee WM, Cheng CY (2013b) Rictor/mTORC2 regulates blood-testis barrier dynamics via its effects on gap junction communications and actin filament network. FASEB J 27:11371152

Moll R, Cowin P, Kapprell H-P, Franke WW (1986) Biology of disease. Desmosomal proteins: new markers for identification and classification of tumors. Lab Invest 54:4-25

Moll R, Sievers E, Hämmerling B, Schmidt A, Barth M, Kuhn C, Grund C, Hofmann I, Franke WW (2009) Endothelial and virgultar cell formations in the mammalian lymph node sinus: endothelial differentiation morphotypes characterized by a special kind of junction (complexus adhaerens). Cell Tissue Res 335:109-141

Mruk DD, Cheng CY (2004a) Cell-cell interactions at the ectoplasmic specialization in the testis. Trends Endocrinol Metab 15:439-447

Mruk DD, Cheng CY (2004b) Sertoli-Sertoli and Sertoli-germ cell interactions and their significance in germ cell movement in the seminiferous epithelium during spermatogenesis. Endocr Rev 25: $747-806$

Mruk DD, Cheng CY (2011) Desmosomes in the testis. Moving into an unchartered territory. Spermatogenesis 1:47-51

Mueller H, Franke WW (1983) Biochemical and immunological characterization of desmoplakins I and II, the major polypeptides of the desmosomal plaque. J Mol Biol 163:647-671 
Nagano T, Suzuki F (1978) Cell to cell relationships in the seminiferous epithelium in the mouse embryo. Cell Tissue Res 189:389-401

Newton SC, Blaschuk OW, Millette CF (1993) N-Cadherin mediates Sertoli cell-spermatogenic cell adhesion. Dev Dyn 197:1-13

Nicander L (1967) An electron microscopical study of cell contacts in the seminiferous tubules of some mammals. Z Zellforsch Mikrosk Anat 83:375-397

Nuber UA, Schäfer S, Schmidt A, Koch PJ, Franke WW (1995) The widespread human desmocollin Dsc2 and tissue-specific patterns of synthesis of various desmocollin subtypes. Eur J Cell Biol 66:69-74

O’Donnell L, Stanton PG, Bartles JR, Robertson DM (2000) Sertoli cell ectoplasmic specialization in the seminiferous epithelium of the testosterone-suppressed adult rat. Biol Reprod 63:99-108

Osman DI (1978) On the ultrastructure of modified Sertoli cells in the terminal segment of seminiferous tubules in the boar. J Anat 127: 603-613

Osman DI, Plöen L (1978) The terminal segment of the seminiferous tubules and the blood-testis barrier. Int J Androl 1:235-249

Paranko J, Virtanen I (1986) Epithelial and mesenchymal cell differentiation in the fetal rat genital ducts: changes in the expression of cytokeratin and vimentin type of intermediate filaments and desmosomal plaque proteins. Dev Biol 117:135-145

Pelletier R-M (1988) Cyclic modulation of Sertoli cell junctional complexes in a seasonal breeder: the mink (Mustela vison). Am J Anat $183: 68-102$

Pelletier R-M (2001) The tight junctions in the testis, epididymis, and vas deferens. In: Cereijido M, Anderson J (eds) Tight junctions, 2nd edn. CRC, Boca Raton, pp 599-628

Pelletier R-M, Byers SW (1992) The blood-testis barrier and Sertoli cell junctions: structural considerations. Microsc Res Tech 20:3-33

Pelletier R-M, Friend DS (1983) The Sertoli cell junctional complex: structure and permeability to filipin in the neonatal and adult guinea pig. Am J Anat 168:213-228

Pfeiffer DC, Vogl AW (2002) Actin-related intercellular adhesion junctions in the germinal compartment of the testis in the hagfish (Eptatretus stouti) and lamprey (Lampetra tridentatus). Tissue Cell $34: 450-459$

Pieperhoff S, Rickelt S, Heid H, Claycomb WC, Zimbelmann R, Kuhn C, Winter-Simanowski S, Frey N, Franke WW (2012) The plaque protein myozap identified as a novel major component of adhering junctions in endothelia of the blood and the lymph vascular systems. J Cell Mol Med 16:1709-1719

Piomboni P (1997) Microanatomy of the epididymis and vas deferens. J Submicrosc Cytol Pathol 29:583-593

Qian X, Mruk DD, Cheng YH, Cheng CY (2013) Actin cross-linking protein palladin and spermatogenesis. Spermatogenesis $3: \mathrm{e} 23473$

Rickelt S (2012) Plakophilin-2: a cell-cell adhesion plaque molecule of selective and fundamental importance in cardiac functions and tumor cell growth. Cell Tissue Res 348:281-294

Rickelt S, Franke WW, Doerflinger Y, Goerdt S, Brandner JM, Peitsch WK (2008) Subtypes of melanocytes and melanoma cells distinguished by their intercellular contacts: heterotypic adherens junctions, adhesive associations, and dispersed desmoglein 2 glycoproteins. Cell Tissue Res 334:401-422

Rickelt S, Rizzo S, Dörflinger Y, Zentgraf H, Basso C, Gerosa G, Thiene G, Moll R, Franke WW (2010) A novel kind of tumor type-characteristic junction: plakophilin-2 as a major protein of adherens junctions in cardiac myxomata. Mod Pathol 23: 1429-1437

Rickelt S, Kuhn C, Winter-Simanowski S, Zimbelmann R, Frey N, Franke WW (2011) Protein myozap - a late addition to the molecular ensembles of various kinds of adherens junctions. Cell Tissue Res 346:347-359

Russell L (1977a) Desmosome-like junctions between Sertoli and germ cells in the rat testis. Am J Anat 148:301-312
Russell L (1977b) Movement of spermatocytes from the basal to the adluminal compartment of the rat testis. Am J Anat 148:313-328

Russell L (1977c) Observations on rat Sertoli ectoplasmic ("junctional") specializations in their association with germ cells of the rat testis. Tissue Cell 9:475-498

Russell LD, Peterson RN (1985) Sertoli cell junctions: morphological and functional correlates. Int Rev Cytol 94:177-211

Schäfer S, Koch PJ, Franke WW (1994) Identification of the ubiquitous human desmoglein, Dsg2, and the expression catalogue of the desmoglein subfamily of desmosomal cadherins. Exp Cell Res 211:391-399

Schmelz M, Franke WW (1993) Complexus adhaerentes, a new group of desmoplakin-containing junctions in endothelial cells: the syndesmos connecting retothelial cells of lymph nodes. Eur J Cell Biol 61:274-289

Schmelz M, Duden R, Cowin P, Franke WW (1986) A constitutive transmembrane glycoprotein of $\mathrm{Mr}$ 165,000 (desmoglein) in epidermal and non-epidermal desmosomes: II. Immunolocalization and microinjection studies. Eur J Cell Biol 42:184-199

Schmidt A, Koch PJ (2008) Desmosomes in development and disease. In: LaFlamme SE, Kowalczyk A (eds) Cell junctions. Adhesion, development, and disease. Wiley-VCH, Weinheim, pp 235-250

Schmitt CJ, Franke WW, Goerdt S, Falkowska-Hansen B, Rickelt S, Peitsch WK (2007) Homo- and heterotypic cell contacts in malignant melanoma cells and desmoglein 2 as a novel solitary surface glyocprotein. J Invest Dermatol 127:2191-2206

Schwechheimer K, Kartenbeck J, Moll R, Franke WW (1984) Vimentin filament-desmosome cytoskeleton of diverse types of human meningiomas. A distinctive diagnostic feature. Lab Invest 51: 584-591

Southwood CM, Gow A (2001) Functions of OSP/claudin-11-containing parallel tight junctions: implications from the knockout mouse. In: Cereijido M, Anderson J (eds) Tight junctions, 2nd edn. CRC, Boca Raton, pp 723-745

Spruill WA, Zyk JR, Tres LL, Kierszenbaum AL (1983) Calcium/ calmodulin-dependent phosphorylation of vimentin rat Sertoli cells. Proc Natl Acad Sci USA 80:760-764

Steger K, Wrobel K-H (1994) Immunohistochemical demonstration of cytoskeletal proteins in the ovine testis during postnatal development. Anat Embryol 189:521-530

Steger K, Schimmel M, Wrobel K-H (1994) Immunocytochemical demonstration of cytoskeletal proteins in seminiferous tubules of adult rams and bulls. Arch Histol Cytol 57:17-28

Stosiek P, Kasper M, Karsten U (1990) Expression of cytokeratins 8 and I8 in human Sertoli cells of immature and atrophic seminiferous tubules. Differentiation 43:66-70

Straub BK, Rickelt S, Zimbelmann R, Grund C, Kuhn C, Iken M, Ott M, Schirmacher P, Franke WW (2011) E-N-cadherin heterodimers define novel adherens junctions connecting endoderm-derived cells. J Cell Biol 195:873-887

Tan ZJ, Peng Y, Song HL, Zheng JJ, Yu X (2010) N-cadherin-dependent neuron-neuron interaction is required for the maintenance of activity-induced dendrite growth. Proc Natl Acad Sci USA 107: 9873-9878

Theis DG, Koch PJ, Franke WW (1993) Differential synthesis of type 1 and type 2 desmocollin mRNAs in human stratified epithelia. Int $\mathbf{J}$ Dev Biol 37:101-110

Uchida N, Honjo Y, Johnson KR, Wheelock MJ, Takeichi M (1996) The catenin/cadherin adhesion system is localized in synaptic junctions bordering transmitter release zones. J Cell Biol 135:767-779

Vogl AW (1989) Distribution and function of organized concentrations of actin filaments in mammalian spermatogenic cells and Sertoli cells. Int Rev Cytol 119:1-56

Vogl AW, Pfeiffer DC, Redenbach DM (1991) Ectoplasmic ("junctional”) specializations in mammalian Sertoli cells: influence of spermatogenic cells. Ann NY Acad Sci 637:175-202 
Vogl AW, Pfeiffer DC, Mulholland D, Kimel G, Guttman J (2000) Unique and multifunctional adhesion junctions in the testis: ectoplasmic specializations. Arch Histol Cytol 63:1-15

Vogl AW, Vaid KS, Guttman JA (2008) The Sertoli cell cytoskeleton. Adv Exp Med Biol 636:186-211

Vogl AW, Young JS, Du M (2013) New insights into roles of tubulobulbar complexes in sperm release and turnover of blood-testis barrier. Int Rev Cell Mol Biol 303:319-355

Wong C-H, Cheng CY (2005) The blood-testis barrier: its biology, regulation, and physiological role in spermatogenesis. Curr Top Dev Biol 71:263-296
Wong C-H, Xia W, Lee NPY, Mruk DD, Lee MW, Cheng CY (2005) Regulation of ectoplasmic specialization dynamics in the seminiferous epithelium by focal adhesion-associated proteins in testosteronesuppressed rat testes. Endocrinology 146:1192-12014

Xia W, Wong CH, Lee NPY, Lee WM, Cheng CY (2005) Disruption of Sertoli-germ cell adhesion function in the seminiferous epithelium of the rat testis can be limited to adherens junctions without affecting the blood-testis barrier integrity: an in vivo study using an androgen suppression model. J Cell Physiol 205:141-157

Yan HHN, Mruk DD, Lee WM, Cheng CY (2007) Ectoplasmic specializations: a friend or foe of spermatogenesis? BioEssays 29:36-48 